\title{
Origin of gem-quality barite at Jebel Ouichane district in Nador, Morocco: implications from integrated fluid inclusions, stable isotopes, and geochemistry
}

Magdalena Dumańska-Słowik ( $\sim$ dumanska@agh.edu.pl )

AGH University of Science and Technology

Naglik Beata

Polish Geological Institute

Tomasz Toboła

AGH University of Science and Technology

Tomasz Powolny

AGH University of Science and Technology

Miłosz Huber

Maria Curie-Skłodowska University

Stanislava Milovska

Slovak Academy of Sciences

Natalia Dobosz

AGH University of Science and Technology

Kamil Guzik

AGH University of Science and Technology

Research Article

Keywords: Barite, fluid inclusion, oxygen isotope geothermometry, calcite, fluid mixing

Posted Date: January 14th, 2021

DOI: https://doi.org/10.21203/rs.3.rs-143678/v1

License: (c) (i) This work is licensed under a Creative Commons Attribution 4.0 International License.

Read Full License 


\title{
Origin of gem-quality barite at Jebel Ouichane district in Nador, Morocco: implications from integrated fluid inclusions, stable isotopes, and geochemistry
}

\author{
Magdalena Dumańska-Słowik ${ }^{1 *}$, Beata Naglik ${ }^{2}$, Tomasz Toboła ${ }^{1}$, Tomasz Powolny ${ }^{1}$, \\ Miłosz Huber ${ }^{3}$, Stanislava Milovska ${ }^{4}$, Natalia Dobosz ${ }^{1}$, Kamil Guzik ${ }^{1}$ \\ ${ }^{1}$ Faculty of Geology, Geophysics, and Environmental Protection, AGH-University of Science and Technology, \\ Krakow 30-059, 30 Mickiewicz Av., Poland.* author for correspondence, e-mail: dumanska@agh.edu.pl \\ ${ }^{2}$ Polish Geological Institute-National Research Institute, Upper Silesian Branch, Królowej Jadwigi 1, 41-200 \\ Sosnowiec, Poland \\ ${ }^{3}$ Department of Geology, Soil Science and Geoinformacy, Faculty of Earth Science and Spatial Management. \\ Maria Curie - Skłodowska University, 2d/107 Kraśnickie Rd, 20-718 Lublin, Poland. \\ ${ }^{4}$ Earth Science Institute, Slovak Academy of Sciences, 1 Ďumbierska str., 97411 Banská Bystrica, Slovakia.
}

\begin{abstract}
Light-blue barite from Jebel Ouichane in Morocco forms blade-like tabular crystals (up to ca. $10 \mathrm{~cm}$ ) with superb transparency and lustre. It represents one of the most spectacular gemquality specimens in the world. The barite is hosted by iron-ore-bearing skarns, developed within Jurassic-Cretaceous limestones, and occurs in close spatial association with calcite. Although it exhibits simple chemical composition, some irregular sectorial zoning, maintained by elevated contents of $\mathrm{Sr}$ in various crystal domains, were found. Barite from Ouichane is abundant in one phase (liquid or gas) or two-phase (liquid-gas) fluid inclusions of primary, pseudosecondary, and secondary origin. A combination of fluid inclusion microthermometry and stable isotope data suggest that $\delta^{18} \mathrm{O}$ value of barite-forming solutions, resulting from mixing of meteoric waters with hydrothermal fluids, could be in the range from $-3,5 \%$ to $+2,7 \%$ o (VSMOW), whereas the main barite crystallization stage falls in the temperatures range of $160-180{ }^{\circ} \mathrm{C}$. The recorded first ice melting temperatures $(-35.9$ to -41.5 ${ }^{\circ} \mathrm{C}$ ) indicate the presence of divalent cations, i.e. $\mathrm{Ca}^{2+}$ and $\mathrm{Mg}^{2+}$ in addition to $\mathrm{NaCl} \pm \mathrm{KCl}$ in the mineralizing fluid composition. The possible source of $\mathrm{SO}_{4}{ }^{2-}$ and $\mathrm{Ba}^{2+}$, which gave rise to the barite formation was fluid enriched in $\mathrm{Ba}, \mathrm{Sr}, \mathrm{Ca}, \mathrm{Mg}, \mathrm{S}$, and other elements derived from the alteration of carbonate and silicate minerals, being components of sedimentary and igneous rocks found in the surroundings of Nador area. Necessary amounts of sulphur could be in turn provided by weathering of pyrite and/or decomposition of organosulphur
\end{abstract}


compounds. The combination of $\delta^{34} \mathrm{~S}$ and $\delta^{18} \mathrm{O}$ values of barite $(+16.39 \%$ and $6.71 \%$, respectively) indicate that its formation occurred in a steam-heated (near-surface) environment.

\section{Keywords}

Barite, fluid inclusion, oxygen isotope geothermometry, calcite, fluid mixing

\section{Introduction}

Barite $\left(\mathrm{BaSO}_{4}\right)$ is ubiquitously distributed in various geological settings since it forms over a large range of pressures and temperatures $\left(1-2000\right.$ bar, $\left.0-400^{\circ} \mathrm{C}\right)$. Hence, this mineral may be hosted by sedimentary deposits and magmatic (or metamorphic) rocks ${ }^{1}$, where it forms massive beds, laminations, rosettes, and/or nodules ${ }^{2}$. The origin of barite is linked to the direct crystallization from supersaturated pore fluids, which contain $\mathrm{Ba}^{2+}$ and $\mathrm{SO}_{4}{ }^{2-}$ derived from the alteration of wall rocks at the oxic-anoxic interface within marine sediments $1,3,4$. Barite may also precipitate directly in the water column marked by the presence of micro-environments, which contain decaying organic matter and other biogenic remains ${ }^{3}$. At last, but not least barite may be formed in association with post-magmatic, hydrothermal activity; e.g. as a result of mixing of late-stage hydrothermal fluids and meteoric waters ${ }^{3-5}$. Finally, some of its deposits may appear through the breakdown of pre-existing evaporates, such as gypsum and anhydrite ${ }^{6,7}$.

Morocco is one of the leading barite producers in the world. Most barite deposits in this region were emplaced during the rift stage assigned to the Triassic-Jurassic period ${ }^{8}$. The Moroccan production mainly comes from three vein-type barite deposits, i.e. Ibel Irhoud, Zelmou, Ht. Seksouaa, Drâa-Tafilalet, as well as widespread small outcrops, frequently exploited by local artisanal miners looking for gem-quality specimens ${ }^{8-10}$.

The barite from the Nador region in Morocco flooded the mineral and gem market in the spring of 2012 at the Sainte Marie Aux Mines show and quickly became very popular on the international mineral fairs and exhibitions ${ }^{11}$. It represents one of the most prominent barite specimens in the world. The highest quality of the species is maintained by such features, as the size of particular crystals (up to $10 \mathrm{~cm}$ ), baby blue coloration contrasting with the surrounding rocks, blade-like fabrics, as well as superb transparency and lustre. Barite specimens originate from the packets and cracks of Jurassic-Cretaceous metasediments exposed in the quarries near Nador in northern Morocco (Sidi Lahcen and Ouichane mines). 
From 2012 till 2015 the quarry's walls changed into "swiss cheese' with many "rats holes" as a result of intensive barite exploitation in this region ${ }^{11}$.

In our contribution, we reconstruct palaeoenvironmental setting (i.e. origin, pathways of mineralizing fluid, and variations in physicochemical conditions during mineral-forming processes) that prevailed during the crystallization of unique and gem-quality, blue barite from Jebel Ouichane quarry in Nador (Morocco). Our constraints are based on fluid inclusion microthermometry, isotopic ( $\mathrm{S}, \mathrm{O}$, and $\mathrm{C}$ ) composition obtained for both barite and paragenetic calcite, supported by the Raman micro-spectroscopy combined with electronmicrobe (EMPA) and X-ray fluorescence (XRF).

\section{Geological setting}

The Jebel Ouichane area, found near Nador city in the north of Morocco, is mainly built of Jurassic limestones with an admixture of clay sediments and subordinately igneous and metamorphic rocks (Fig. 1) ${ }^{12,13}$. On the slope of the Ouichane Mountain, there is a closed quarry complex hosting barite nodules, which was the important source of iron ore to many countries of western Europe during the first half of the $20^{\text {th }}$ century. The mineralization, mainly in the form of magnetite, hematite, limonite, pyrite, and rarely chalcopyrite and pyrrhotine, has likely resulted from the contact metamorphism of the Miocene quartz diorite porphyry intrusion to the country rocks built of Jurassic limestone ${ }^{11}$. As noted by Bouabdellah et al. ${ }^{13}$, there is the concordance between the timing of mineralization $(7.04 \pm$ $0.47 \mathrm{Ma})$ and the crystallization age of the Ouichane quartz-diorite porphyry $(7.58 \pm 0.03$ $\mathrm{Ma}$ ), which provides strong evidence for a genetic relationship between ore mineralization and Late Neogene magmatism.

As a result of this metasomatism, skarn-type raw materials with high contents of iron, coupled with low sulphur amounts, were mined from Jurassic-Cretaceous metasediments. However, with the increased demand, and thus the deepening of the ore extraction range, it was noted that the deeper into the ore, the greater the proportion of pyrite to magnetite in the ore was found. This situation was associated with additional desulphurization costs and reduced profitability of ore extraction, and in consequence, led to the complete closure of the mine in $1950^{12}$.

In the vicinity of Ouichane mountain, Jurassic limestone dips $30^{\circ}$ from the top towards the north to the exploited iron deposit. In the outcrop, there is pure limestone in the form of large banks with a maximum thickness of $250 \mathrm{~m}$, being slightly converted into marble in that 
region. In the north-western part of the mine, i.e. about $20 \mathrm{~m}$ below its border, rapid changes in the facies composition are noted. The pure and partially metamorphosed limestone gradually changes into a series of clay rocks. The stratification of that facies is quite complicated due to many sedimentary and tectonic processes recognized in this region, proved by the series of hollows, faults, micro-cracks, etc. ${ }^{12,13}$.

In the valleys, north of the deposit in the Ouichane mountain, the Jurassic-Cretaceous limestone is covered heterogeneously by a series of post-orogenic yellow sandy clays, marls, and conglomerates assigned to the early Tertiary period. All these sediments are covered with tuffs and biotite andesites coming from the former Gourougou stratovolcano found to the west of Melilla and other smaller adjacent craters in that region ${ }^{12}$. Igneous rocks from the study area are chiefly represented by granitic to dioritic rocks containing many argillite "inserts". Quartz and plagioclase aplites, microdiorites, and porphyry micromonzonites are also abundant in this area ${ }^{12,13}$. The contact metamorphism of limestone and argillite is negligible, often limited to the recrystallization zone, i.e. $<1 \mathrm{~m}$ within limestone and less than a few $\mathrm{cm}$ in the intruding zones of argillites ${ }^{12}$.

\section{Results}

Barite forms well-crystallized, bladed-tabular, light-blue crystals with average sizes of $3.0-4.0 \mathrm{~cm}$, locally reaching up to $10 \mathrm{~cm}$. The thin individual plates/blades are frequently arranged parallel to each other and grouped in the characteristic clusters (Fig.2). Rarely, they were found in either radiating bundles or euhedral tabular crystals that project into open vugs. The aggregates of barite are commonly found on the matrix of host ore-bearing skarn. Occasionally, they occur on a matrix of coexisting white-grey calcite.

\section{Petrography of barite bearing rock}

The barite host rock is mainly composed of Fe oxides/hydroxides such as haematite, goethite, magnetite, and subordinately carbonates, i.e. calcite and siderite. Hematite is the major component of the rocks while its formation is linked to various stages of martitization (Fig. 3A-B). This process proceeded along the edges of crystal faces, from the rim toward the core of the magnetite grains. As a result, newly formed haematite usually shows a mesh or collomorphic microtextures (Fig. 3C-D). Calcite appears as rhombohedral crystals with characteristic polysynthetic twinning. Siderite and calcite occur as small aggregates or filling 
thin veins intersecting the rock. Mn-oxides, chalcopyrite, and pyrite are accessory components of the rock.

\section{Microscopic observations}

Barite crystals analysed both in parallel and perpendicular sections host an abundance of fluid inclusions exhibiting various shapes that slightly resemble flags, feathers, or wings. Most of the inclusions are one-phase and composed of either liquid or gas (Fig. 4A). Only some of them exhibit characteristic tails (Fig. 4B) triggered by the necking down process ${ }^{14}$. Rarely, two-phase (liquid and vapour) inclusions were observed. The size of inclusions usually ranges from a few $\mu \mathrm{m}$ to $30 \mu \mathrm{m}$, although larger inclusions were also found.

Fluid inclusion assemblages (FIAs) are arranged in trails or form large and irregularly shaped groups occurring in individual planes (Fig. 4C). Sometimes, the FIAs exhibit linear course and excessively elongated irregular shapes of inclusions, which give the impression of longitudinal stripes arranged parallel to each other.

The small, rounded, or oval-shaped dark inclusions form thin, dashed planes that overlap without causing any shifts. This is the result of healing the cracks, which had taken place in the past. Such occurrence of FIAs suggests their secondary origin, while the huge number of healed fractures indicates that the host mineral had contained many cracks and fissures crossing each other at right angles.

Other trails of inclusions are found along the edges of the crystal face. The sequences of such FIAs end with a gradually decreasing number and size of individual inclusions, but not reaching the edges of the crystal. These are the primary originated inclusions, which were formed with the growth of the host barite crystal.

Some fluid inclusions form groups arranged perpendicular to the crystal face as they cut across the edges of the crystals (Fig.4C). Their course and manner of ending prove their secondary genesis.

Moreover, the numerous groups of rectangle-shaped and violet-coloured inclusions were also observed (Fig.4D). They are one phase inclusions composed of liquid. Their geometry and arrangement may suggest pseudosecondary or secondary genesis. A concentration of the solid phase with a brown colour resembling an organic substance was also observed within the host barite.

Calcite, occasionally accompanying barite crystals, shows numerous solid inclusions. They occur the most often in the central part of calcite crystals in the form of densely packed 
individuals (Fig.5A). The size of the inclusions range from $\sim 5$ to $\sim 50 \mu \mathrm{m}$ and their shape is irregular. In the outer part of the crystals, the solid inclusions form zones and disappear completely in the outermost parts of the crystals. Fluid inclusions in calcite crystals are very rare. They form very small (up to $\sim 2 \mu \mathrm{m}$ ) individuals filled with liquid phase (Fig.5B).

\section{Microthermometry of fluid inclusions}

Primary inclusions were distinguished based on their mode of occurrence following the rules provided by Roedder ${ }^{14}$. They mostly form randomly distributed groups, followed by scarce, isolated individuals. In general, one-phase inclusions predominate over two-phase inclusions.

During heating experiments, all inclusions underwent homogenization to the liquid phase at temperatures ranging from 143.3 to $243.7^{\circ} \mathrm{C}$ (Tab.1). If a few highest temperatures (above $200^{\circ} \mathrm{C}$ ) are not considered with the other results, the narrow range of Th might be representative for conditions of barite precipitation.

During freezing experiments, the initial ice melting took place at temperatures from the range of -35.9 to $-41.5{ }^{\circ} \mathrm{C}$ (Tab.1). It means that the chemical composition of inclusion is more complex with some divalent cations such as $\mathrm{Ca}^{2+}$ and $\mathrm{Mg}^{2+}$. The melting temperature represents the little diversified values ranging from -0.2 to $0.0^{\circ} \mathrm{C}$ and corresponding to the very low salinity, which spans from 0.00 to $0.35 \% \mathrm{NaCl}$ eq. ${ }^{15}$.

\section{$X$-ray Fluorescence}

Semi-quantitative chemical analysis (Tab.2) and elemental areal mapping of barite crystal aggregate show enrichment in $\mathrm{Ca}, \mathrm{Cu}, \mathrm{K}, \mathrm{Fe}, \mathrm{Sr}$, and $\mathrm{Zn}$. The indistinctive sectorial zoning of $\mathrm{Ba}$ and $\mathrm{Sr}$ distribution was observed (Fig. 6). The elevated concentration of $\mathrm{Sr}$ and $\mathrm{K}$ was obtained in specified crystal zones, whereas the other zones are depleted by those elements. Sr accumulates in the central part of the crystals, particularly.

\section{Electron Microprobe Analyses (EMPA)}

Blue barite from Nador has a simple and relatively homogenous composition (Tab.3). It contains 60.09-66.01 wt.\% of $\mathrm{BaO}$ and 34.63-35.30 wt.\% of $\mathrm{SO}_{3}$. $\mathrm{Ba}$ is only locally substituted by $\mathrm{Sr}(0.00-2.59$ wt.\% $\mathrm{SrO}), \mathrm{Na}$ (0.00-0.11 wt.\% $\left.\mathrm{Na}_{2} \mathrm{O}\right), \mathrm{Al}$ (0.03-0.13 wt.\% $\left.\mathrm{Al}_{2} \mathrm{O}_{3}\right)$ and $\mathrm{Ca}(0.00-0.09$ wt.\% $\mathrm{CaO}$ ). As a result, under BSE imaging barite shows distinct zoning. The darker patches are more enriched in Sr relative to lighter patches in the crystals. 
The strong negative correlations were observed between $\mathrm{SrO}$ vs $\mathrm{BaO}(\mathrm{R}=-0.97)$ and $[\mathrm{SrO}+\mathrm{CaO}]$ vs $\mathrm{BaO}(\mathrm{R}=-0.98)$.

\section{Raman Micro-spectroscopy}

The Raman spectrum of barite (Fig. 7) consists of an intense $v_{1}$ band, which corresponds to the nondegenerate symmetric stretching of $\mathrm{SO}_{4}$ tetrahedra at $987 \mathrm{~cm}^{-1}{ }^{16}$. The other characteristic bands $v_{2}, v_{3}$ and $v_{4}$, were found at: $v_{2}-452 \mathrm{~cm}^{-1}$ and $461 \mathrm{~cm}^{-1} ; v_{3}-1083$ $\mathrm{cm}^{-1}, 1139 \mathrm{~cm}^{-1}$ and $1165 \mathrm{~cm}^{-1} ; v_{4}-616 \mathrm{~cm}^{-1}$ and $646 \mathrm{~cm}^{-1}$. They arise from double degenerate, symmetric bending $\left(v_{2}\right)$, triple degenerate asymmetric stretching $\left(v_{3}\right)$, and triple degenerate asymmetric bending $\left(v_{4}\right)$ vibrations ${ }^{16,17}$. The extra low-intensity band at $1103 \mathrm{~cm}^{-1}$ could be attributed to $v_{3}$ mode in the sulphate ${ }^{18}$. The bands below $400 \mathrm{~cm}^{-1}$ belong to the vibration of the bonds between $\mathrm{Ba}-\mathrm{O}^{16}$.

The coupling between Raman spectroscopic studies and EMPA data revealed that positions of diagnostic Raman bands have mostly remained unaffected by negligible variations of the main element composition of barite. Only slight variations were observed in the lower range of Raman shift, i.e. $400-500 \mathrm{~cm}^{-1}$. The variable proportions of the peak heights at $461 \mathrm{~cm}^{-1}$ and $452 \mathrm{~cm}^{-1}$ were noted (Fig. 7 inset). The relationship between the ratio of the height of both peaks $\left(\mathrm{H}_{451} / \mathrm{H}_{461}\right)$ and the $\mathrm{SrO}$ content (wt.\%) in the whole population of analytical points shows no correlation.

Raman spectra collected from fluid inclusions in barite showed only the presence of the bands attributed to the host crystal (Fig.8). These observations infer that FIAs are chiefly composed of water solutions.

For the solid inclusions hosted in calcite crystals, Raman spectroscopy revealed the presence of chalcophanite (Fig. 9A) and goethite (Fig. 9B). The marker bands for chalcophanite occur at 483,511,542, and $690 \mathrm{~cm}^{-1}$, which well correspond with data reported by Julien et al. ${ }^{19}$. The presence of goethite is proved by three Raman bands at 242, 299, 389 $\mathrm{cm}^{-1}$, cf. Das and Henry ${ }^{20}$. The fluid inclusions do not show any admixture of gases and compounds, which can be distinguished by Raman microspectroscopy.

\section{Stable Isotope data}

The sulphur $\left(\delta^{34} \mathrm{~S}\right)$ and oxygen isotope $\left(\delta^{18} \mathrm{O}\right)$ values in blue barite are measured to be $+16.39 \%$ (VCDT) and $+6.71 \%$ (VSMOW), respectively. The coexisting calcite has the carbon isotope $\left(\delta^{13} \mathrm{C}\right)$ values $-8.38 \%$ (VPDB), and oxygen isotope $\left(\delta^{18} \mathrm{O}\right)$ is $+22.90 \%$ 
(VSMOW). The comparison of the obtained results with isotopic data reported from various geological settings is shown in Fig. 10.

\section{Discussion}

The form of occurrences of barite, i.e. open space and vugs filling the host rocks, and/or overlying the calcite matrix implies its epigenetic character. The crystallization of paragenetic calcite had possibly occurred prior to the barite's formation. This process involved not only significant amounts of $\mathrm{Ca}$ and $\mathrm{CO}_{3}$, but also iron and manganese, which are now bounded in the cogenetic inclusions of chalcophanite and goethite within calcite. The distribution of these mineral inclusions indicates that the content of manganese and iron gradually decreased during the crystallization of calcite.

The morphology of barite from Jebel Ouichane in the form of tabular-bladed, welldeveloped rhomboidal crystals shapes suggests slow crystal growth rates at a relatively low supersaturation level and under control of a surface reaction precipitation mechanism ${ }^{21}$. The well-formed morphology and relatively large size of gem-quality barite crystals are surely caused by the availability of surface area for their growth in open vugs of Fe ore-bearing skarns hosted by Jurassic limestones.

The composition of barite is close to ideal stoichiometric. In its structure $\mathrm{Ba}$ is only locally replaced by $\mathrm{Sr}(0.00-0.06 \mathrm{apfu})$. The partitioning of $\mathrm{Ba}$ and $\mathrm{Sr}$ accounts for fluctuations in fluid compositions resulting from fractionation between these elements. In general, Sr shows variations within the individual growth zones since it mainly concentrates in the inner domains of the barite crystals. Such behaviour may reflect diffusion-controlled rates of transport of $\mathrm{Sr}$ and $\mathrm{Ba}$ to sites of their precipitation ${ }^{1}$. Moreover, chemical zonation in barite may indicate that the very first stage of barite precipitation was characterized by a relatively high growth rate, followed by relatively high supersaturation conditions and rapidly oscillating temperature conditions ${ }^{22}$. Over time, where the crystal zones became wider and wider, the fluid could be less saturated, and environmental conditions have changed towards more stable.

\section{Temperature condition of barite precipitation}

Barite, as a soft and cleavable mineral, provides a very challenging material for microthermometric analysis due to the high susceptibility of its inclusions to stretching or 
decrepitation. As concluded by Ulrich and Bodnar ${ }^{23}$, the appearance of internal pressure required to initiate stretching of inclusions might result from samples overheating during the microthermometric experiments. Despite those methodological difficulties a lot of barite crystals representing various geological systems were successfully examined using microthermometry with the conclusions on their origin and metallogenesis ${ }^{24-28}$. Barite-hosted inclusions might provide valuable data on $\mathrm{p}$-T conditions of host crystal growth; however, the measurements must be performed with special care. In the studied case no stretching was observed as it was supposed from the chemical composition of inclusions revealed by Raman micro-spectroscopy to be dominated by $\mathrm{H}_{2} \mathrm{O}$. Ulrich and Bodnar ${ }^{23}$ concluded that inclusions bearing such gases as $\mathrm{CO}_{2}, \mathrm{CH}_{4}$, and $\mathrm{H}_{2} \mathrm{~S}$ are extremely susceptible to stretching.

The homogenization temperatures (Th) revealed the values from 143 to $243^{\circ} \mathrm{C}$ for 73 fluid inclusions, with the mean value of $181^{\circ} \mathrm{C}$ and standard deviation $(\sigma)$ of $23^{\circ} \mathrm{C}$. The distribution of these temperatures could be described as unimodal (Fig. 11) and shows positive (right) skewness of $0.90(-)$. Moreover, almost $36 \%$ of measured temperatures fall in the range of $160-180^{\circ} \mathrm{C}$, which could be regarded as the main stage of barite formation. This conclusion stays in good agreement with fluid inclusions data obtained for other minerals representing a late retrograde stage of mineralization, i.e. quartz and calcite, which homogenize under a temperature range of 250 to $125^{\circ} \mathrm{C}^{13}$.

The predominance of monophase inclusions in barite is considered as an indicator of lowtemperature conditions of crystals growth; however microthermometric data indicate a rather low- to a medium-temperature hydrothermal environment of its precipitation. Hence, the precipitation temperature of barite was estimated also using the isotope fractionationtemperature equation proposed by Kusakabe and $\mathrm{Chiba}^{29}$, i.e.:

$10^{3} \ln \alpha$ mineral-water $=3.01\left(10^{6} / \mathrm{T}^{2}\right)-7.3$, where:

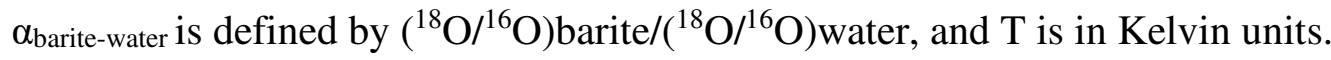

It was assumed that the oxygen isotopic composition of barite-forming fluid corresponds to the value for meteoric waters, i.e. $-7.0 \%$ (VSMOW) ${ }^{30}$. As a result, the determined temperature was calculated at $106^{\circ} \mathrm{C}$, which is lower than the values obtained from microthermometry. Thus, the discrepancy between temperatures obtained from isotopic data and fluids inclusion studies could be explained by the mixing of meteoric and hydrothermal fluids of unknown $\delta^{18} \mathrm{O}$ characteristics. To obtain a similar temperature range of barite crystallization as from microthermometry, $\delta^{18} \mathrm{O}$ characteristics of mineralizing fluid should be 
assumed to follow the range of $-3,5 \%$ o to $+2,7 \%$ (VSMOW). The interpretation of our results stays in agreement with data obtained by Bouabdellah et al. ${ }^{13}$, who concluded that sulphides and calcite-barite assemblages hosted in skarn of Ouichane deposit were deposited due to mixing of hydrothermal fluids with external dilute solutions. Much earlier, under the temperature range of $500-400{ }^{\circ} \mathrm{C}$, iron oxides (magnetite-hematite) had crystallized ${ }^{13}$.

\section{Timing and origin of barite mineralization}

The sulphur isotope data of barite $(+16.39 \%$ VCDT $)$ could be used as a premise for the nature of $\mathrm{Ba}$ and $\mathrm{SO}_{4}$-rich fluids. Such high isotopic value is probably associated with the migration of barite-forming solutions within rocks enriched in the sulphur of organic origin ${ }^{31-}$ ${ }^{33}$, as it is generally accepted that organosulphur compounds are enriched in heavy $\mathrm{S}$ isotope relative to the coexisting sulphides ${ }^{34}$. Additionally, the sulphur isotopic composition of the barite is not only consistent with the values adopted for evaporates of the Mesozoic age ${ }^{35}$, but also covers the range of hydrothermal sulphates described by i.e. Jurkowić et al. ${ }^{36}$. For the oxygen delta, the isotopic value found at $+6,71$ VSMOW (Fig. 10) is characteristic of meteoric water infiltration ${ }^{37}$, but also stays in agreement with the composition of fluids related to volcanic activity (Fig. 10).

The depletion in the heavy carbon isotope of coexisting calcite (-8.38 VPDB) points to the magmatic affinity of mineral-forming ( $\mathrm{CO}_{2}$-bearing fluids), which could originate from i.e. igneous country rocks ${ }^{38,39}$ - see Fig. 10 . On the contrary, oxygen delta (+22.90 VSMOW) in calcite is characteristic of marine solutions (Fig. 10) and stays in agreement with stable isotopes of oxygen-18 values of Mesozoic sediments (including carbonate rocks ${ }^{35,40}$. The discrepancy between the oxygen delta of calcite $(+22.90)$ and barite $(+6,71)$ might, in turn, indicate that calcite formed first via dissolution and decarbonation of pre-existing limestones by magmatic-related waters, whereas barite-forming parental fluids were derived from variable sources.

To determine the source of sulphate necessary for barite crystallization three potential alternatives were discussed: (1) direct dissolution of evaporites, (2) oxidation of sulphide minerals, or (3) mineralization of organic substance ${ }^{41}$. In Nador, evaporite deposits are not known to exist in the rock sequences of that area, so they could not be considered as a possible source of the sulphate. The abundant amount of pyrite was found within the JurassicCretaceous limestones that occupy the study area ${ }^{13}$. Hence, the production of sulphate as a 
result of sulphide oxidation might seems to be probable in this geological setting. On the other hand, both pyrite and barite are low-temperature minerals that could both form contemporaneously, as a result of hydrothermal activity. Finally, the enrichment in heavy S isotope data supports the organic origin of sulphur, which could be derived from i.e. thermal decomposition of organosulphur compounds in the limestones ${ }^{33,41}$. The relationship between $\delta^{34} \mathrm{~S}$ and $\delta^{18} \mathrm{O}$ data of barite can be explained by the mixing of magmatic-hydrothermal sulphate with steam-heated $\mathrm{SO}_{4}$ from the oxidation of $\mathrm{H}_{2} \mathrm{~S}$ near the earth surface ${ }^{5}$. The source of barium for barite precipitation was probably aqueous fluids enriched in $\mathrm{Ba}, \mathrm{Sr}, \mathrm{Al}, \mathrm{K}$, and $\mathrm{Na}$ derived from the alteration of silicate (feldspars) and carbonate minerals (calcite), being components of sedimentary (siliciclastic rocks) and igneous rocks (diorites, granites, andesites) found in the vicinity of Jebel Ouichane.

\section{Conclusions}

1. Gem-quality light-blue barite from Jebel Ouichane (Nador) displays simple chemical composition accompanied by local substitution of $\mathrm{Ba}$ by $\mathrm{Sr}$ (up to 2.59 wt. \% of $\mathrm{SrO}$ ), mainly in the inner regions of particular crystals. According to microthermometric data, the mineral formed in the temperature range of $143-243^{\circ} \mathrm{C}$.

2. Barite shows moderately-high enrichment in heavy sulphur isotope $\left(\delta^{34} S=+16.39\right.$ $\%$ VCDT) derived from i.e. leaching of diagenetic sulphides (pyrite) and/or organic sulphur compounds from the enclosing limestones. A relatively low $\delta^{16} \mathrm{O}$ value $\left(+6.71 \%\right.$ ) indicates that barite formation was favoured by oxidation of $\mathrm{H}_{2} \mathrm{~S}$ in a nearsurface environment.

3. Mixing of hydrothermal-magmatic solutions with meteoric waters could be regarded as the major mechanism responsible for the formation of barite from the Nador area. Furthermore, the calculated $\delta^{18} \mathrm{O}$ values of barite-forming (for $\mathrm{Ba}$ - and $\mathrm{SO}_{4}$-rich) parental fluids fall between $-3,5 \%$ to $+2,7 \%$ (VSMOW).

4. High $\delta^{34} \mathrm{O}$ values coupled with low $\delta^{34} \mathrm{C}$ values (+22.90 and $-8.38 \%$, respectively) of the paragenetic calcite may reflect the decarbonation of pre-existing sedimentary carbonates during metasomatic interactions between magmatic-related fluids and Jurassic limestones found in the study area. 
5. The probable sequence of crystallization in Ouichane iron deposit could proceed as follows: (1) iron oxides mineralization within skarns, (2) deposition of calcite abundant in iron and manganese solid inclusions, (3) formation of gem-quality barite devoid of any ore-bearing inclusions.

\section{Methods}

Barite and coexisting calcite samples were investigated in this work using microscopic, spectroscopic, micro-chemical, and isotopic methods. The presence of fluid inclusions was described using optical microscopy and supported by microthermometry. The maps of element distribution in barite clusters were obtained with micro X-ray Fluorescence. The detailed geochemistry of barite in the micro-region was obtained with electron microprobe analyses. The chemical data were correlated with the results of Raman microspectroscopy. The temperatures of crystallization of barite and calcite were additionally estimated with isotope analyses.

Optical, Electron microprobe, and Raman analyses were conducted in the laboratories of the Faculty of Geology, Geophysics, and Environmental Protection at AGH - The University of Science and Technology in Krakow, Poland. Microthermometry and X-ray Fluorescence analyses were made in the Earth Science Institute, Slovak Academy of Sciences in Banská Bystrica, Slovakia. Sulphur, oxygen, and carbon analyses were made in the Mass Spectrometry Laboratory of the Institute of Physics of the Maria Curie-Skłodowska University in Lublin, Poland.

\section{Optical microscopy}

The iron ore, which hosts barite crystals, was analysed with Olympus BX 51 polarizing microscope with a magnification ranging from $40 \times$ to $400 \times$. The observations were conducted using both transmitted and reflected light modes. The photomicrographs were acquired using an Olympus DP12 digital camera equipped with the Analysis software. The wafers and thin sections of barite and calcite crystals were examined with both Motic SMZ168 binocular with a magnification range of $0.5 \mathrm{x}, 1 \mathrm{x}, 2 \mathrm{x}, 3 \mathrm{x}, 4 \mathrm{x}, 5 \mathrm{x}$ and Motic BA310Pol polarizing microscope with objectives of $4 \mathrm{x}, 10 \mathrm{x}, 40 \mathrm{x}$, and $60 \mathrm{x}$ to provide the general description of various kinds of inclusions in both minerals.

\section{Microthermometry}


Barite-hosted primary fluid inclusions were analyzed on double-polished wafers $(0.2 \mathrm{~mm}$ thick) by using Linkam FTIR600 stage mounted on the ZEISS AxioScope A1 microscope with magnification objectives of $10 \times, 50 \times$, and $100 \times$, equipped with QImaging Micro Publisher 5.0 RTV camera. Equipment was available for studies at the Slovak Academy of Sciences in Banska Bystrica. The calibration of the stage was carried out using natural inclusions of pure $\mathrm{CO}_{2}$, and chemical compounds with known temperatures of phase transitions. The fluid inclusions were subjected to temperatures in the range from $-50^{\circ} \mathrm{C}$ to $+250^{\circ} \mathrm{C}$. The heating runs were made at the rate of $10^{\circ} \mathrm{C} / \mathrm{min}$ until the homogenization was approaching. Afterward, the temperature was raised by a step of $1^{\circ} \mathrm{C} / \mathrm{min}$.

Homogenization (Th), eutectic (Te), and final ice melting (Tm) temperatures were measured. No pressure correction to homogenization temperatures was applied, since trapping pressure is low in epithermal systems ${ }^{42}$. To avoid or minimized stretching effects on samples a proper analytical procedure was adopted in this study: (1) Heating experiments were provided before freezing; (2) Temperature was increased only when all low-Th inclusions reached their homogenization temperatures; (3) All inclusions have been observed continuously during heating from room temperature to the homogenization temperature to perceive any evidences of stretching; (4) Mostly small and round inclusions were studied; (5) A cycling technique was used.

Samples devoid of two-phase inclusions at room temperature were previously cooled to induce the vapor nucleation. Such an approach has been previously presented by many authors ${ }^{24,25}$ with no stretching effects on inclusions.

\section{$X$-ray Fluorescence spectrometry}

The Energy-dispersive micro X-ray Fluorescence Spectrometry analysis was performed using the M4 TORNADO (Bruker) spectrometer. The maps of elements distribution were obtained from the selected area of $29 \mathrm{~mm}$ x $18.4 \mathrm{~mm}$ within a polished crystals aggregate. The excitation current (Rh anode) was $600 \mu \mathrm{A}$ at $50 \mathrm{kV}$. The analyses were carried out in a vacuum of 20 mbar, the distance between the two measurement points was $15 \mu \mathrm{m}$, at a speed of $20 \mathrm{~ms} /$ pixel. The SDD detector that collects the fluorescent signal has an active area of $30 \mathrm{~mm} 2$ and a spectral resolution of $145 \mathrm{eV}$. Elements concentration was computed by the fundamental parameters method.

\section{Electron microprobe microanalyses}


EPMA analyses were performed with a JEOL Super Probe JXA-8230 operating in a wavelength-dispersive (WDS) mode under the following conditions: an accelerating voltage of $15 \mathrm{kV}$, a beam current of $20 \mathrm{nA}$, beam size of $2 \mu \mathrm{m}$, a peak count-time of 20 seconds, and a background time of 10 seconds. The EMPA standards, analytical lines, diffracting crystals, and mean detection limits were as follows: Na- albite_SPI (K $\alpha$, TAP, 478 ppm), Sr-celestine

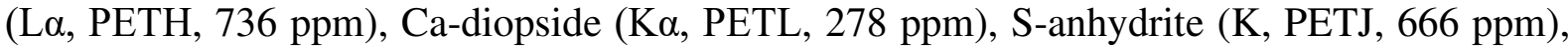
Ba-barite (La, PETL, 741 ppm). The other analysed elements such as Al, Mg, Mn, Fe, Cl, Pb, $\mathrm{L}, \mathrm{Zn}, \mathrm{Cu}$ were under the detection limit of the method. The JEOL ZAF procedure was used for the matrix correction of the raw data.

\section{Raman micro-spectroscopy}

Raman spectra of barite and inclusions hosted in them were recorded with a Thermo Scientific DXR Raman microscope featuring 10x, 50x, and 100x magnification objectives. The samples were excited with a $532 \mathrm{~nm}$ high-power laser. Laser power was from 5 to 10 $\mathrm{mW}$, the exposure time was $3 \mathrm{~s}$, the number of exposures -10 times. The laser focus diameter was approximately $2.1-0.7 \mathrm{~mm}$. The spectra were corrected for background by a method of a sextic polynomial using Omnic software. Raman analyses were made both on clean cleavage surfaces and doubly polished wafers. Raman studies were performed in the same analytical spots of barite, for which chemical analyses were carried out using the EMPA method to trace the differences in the position of individual Raman bands in the points differing in the $\mathrm{Sr}$ contents.

\section{Isotope analyses}

The isotope ratios of barite $\left(\delta^{34} \mathrm{~S}\right.$ and $\left.\delta^{18} \mathrm{O}\right)$ were determined by measuring the isotopic composition of $\mathrm{SO}_{2}$ and $\mathrm{CO}_{2}$ gases on a dual-inlet and triple collector mass spectrometer. Sulphur in the form of $\mathrm{SO}_{2}$ gas was quantitatively extracted from the $\mathrm{BaSO}_{4}$ sample by thermal decomposition at $850{ }^{\circ} \mathrm{C}$ in a $\mathrm{Cu}$ boat in the presence of $\mathrm{Na}_{2} \mathrm{PO}_{4}$ reagent ${ }^{43,44} \cdot \mathrm{CO}_{2}$ gas was prepared by graphite reduction with the conversion of $\mathrm{CO}$ to $\mathrm{CO}_{2}$ by glow discharge ${ }^{45}$. Nearly quantitative $\mathrm{CO}$ to $\mathrm{CO}_{2}$ conversion was attained using a magnetic field in the conversion unit ${ }^{46}$. The rough delta values were normalized to the Vienna-Canyon Diablo Troilite (VCDT) and the Vienna Standard Mean Ocean Water (VSMOW) standards by analysis of the $\mathrm{SO}_{2}$ and $\mathrm{CO}_{2}$ raw isotopic ratios prepared from the NBS-127 standard, for which we assumed $\delta^{34} \mathrm{~S}=21.17 \%{ }^{43}$ and $\delta^{18} \mathrm{O}=8.73 \%{ }^{46}$. 
For the accompanying calcite, the $\delta^{13} \mathrm{C}$ and $\delta^{18} \mathrm{O}$ values were determined as well. $\mathrm{CO}_{2}$ gas was extracted from calcite at $25{ }^{\circ} \mathrm{C}$ by reaction with $\mathrm{H}_{3} \mathrm{PO}_{4}{ }^{47}$ and measured on an isotope-ratio mass spectrometer with a dual-inlet system. The standard deviations of measurements for the NBS19 international standard were better than 0.1\%. Delta values were normalized to the Vienna Pee-Dee Belemnite (VPDB).

\section{Acknowledgments}

We are grateful to Tomasz Praszkier for providing samples for the study and data on the sampling area. Jarmila Luptáková and Adam Włodek are acknowledged for their assistance in microthermometric measurements and EMPA analyses, respectively. The research was financially supported by AGH University of Science and Technology, research grant no. 16.16.140.315.

\section{Author contributions}

M.D., B.N., T.T. and T.P designed the experiments, interpreted the data, wrote the manuscript, and prepared figures and photographs. S.M., M.H., N.D. and K.G. performed the experiments and interpreted the data.

\section{References}

1. Hanor, J. S. Barite-celestine geochemistry and environments of formation. in Reviews in Mineralogy \& Geochemistry - Sulfate Minerals (eds. Alpers, C. N., Jambor, J. L. \& Nordstrom, D. K.) 40, 193-275 (Mineralogical Society of America, 2000).

2. Bonny, S. M. \& Jones, B. Controls on the precipitation of barite (BaSO4) crystals in calcite travertine at Twitya Spring, a warm sulphur spring in Canada's Northwest Territories. Sediment. Geol. 203, 36-53 (2008).

3. Paytan, A., Mearon, S., Cobb, K. \& Kastner, M. Origin of marine barite deposits: Sr and S isotope characterization. Geology 30, 747-750 (2002).

4. Griffith, E. M. \& Paytan, A. Barite in the ocean - occurrence, geochemistry and palaeoceanographic applications. Sedimentology 59, 1817-1835 (2012).

5. Rye, R. O. A review of the stable-isotope geochemistry of sulfate minerals in selected igneous environments and related hydrothermal systems. Chem. Geol. 215, 5-36 (2005).

6. Mossman, D. J. \& Brown, M. J. Stratiform barite in sabkha sediments, Walton- 
Cheverie, Nova Scotia. Econ. Geol. 81, 2016-2021 (1986).

7. Warren, J. K. Evaporites: Sediments, Resources and Hydrocarbons. (Springer-Verlag, 2006).

8. Jébrak, M., el Wartiti, M., Marcoux, E. \& Zaharoui, M. The Bouznika Cambrian barite deposit (Morocco), an early mineralization on the Iapetus margin. J. African Earth Sci. 60, 53-62 (2011).

9. Margoum, D. et al. Pangea rifting and onward pre-Central Atlantic opening as the main ore-forming processes for the genesis of the Aouli REE-rich fluorite-barite vein system, Upper Moulouya District, Morocco. J. African Earth Sci. 108, 22-39 (2015).

10. Essalhi, M., Mrani, D., Essalhi, A., Toummite, A. \& Ali-Ammar, H. Evidence of a high quality barite in Drâa-Tafilalet region, Morocco: a non- upgraded potential. J. Mater. Environ. Sci. 9, 1366-1378 (2018).

11. Praszkier, T. Baryt - vielfältige Vorkommen in Marokko. extraLapis 48, 32-43 (2015).

12. Rhoden, N. H. Geologie du gisement de fer d' Quichane (Rif nord oriental). Mines Geol. 4, 63-70 (1961).

13. Bouabdellah, M., Jabrane, R., Margoum, D. \& Sadequi, M. Skarn to PorphyryEpithermal Transition in the Ouixane Fe District, Northeast Morocco: Interplay of Meteoric Water and Magmatic-Hydrothermal Fluids. in Mineral Deposits of North Africa (eds. Bouabdellah M. \& J.F., S.) 201-225 (Springer International Publishing, 2016). doi:10.1007/978-3-319-31733-5_7

14. Roedder. Fluid Inclusions. Reviews in Mineralogy, vol. 12 (Mineralogical Society of America, Book Crafters, Inc, 1984).

15. Bodnar, R. J. \& Vityk, M. O. Interpretation of microthermometric data for H2O-NaCL fluid inclusions. in Fluid Inclusions in Minerals: Methods and Application 117-130 (Virginia Tech, 1994).

16. Buzgar, N., Buzatu, A. \& Sanislav, I. V. The raman study of certain sulfates. Analele Ştiinţifice ale Univ. Alexandru Ioan Cuza” Iaşi, Ser. Geol. 55, 5-23 (2009).

17. Dimova, M., Panczer, G. \& Gaft, M. Spectroscopic study of barite from the Kremikovtsi Deposit (Bulgaria) with implication for its origin. Ann. Géologiques La Péninsule Balk. 67, 101-108 (2006).

18. Kloprogge, J. T., Ruan, H., Duong, L. V. \& Frost, R. L. FT-IR and Raman microscopic study at $293 \mathrm{~K}$ and $77 \mathrm{~K}$ celestine, SrSO4, from the middle triassic limestone (Muschelkalk) in Winterswijk, The Netherlands. Geol. en Mijnbouw/Netherlands J. Geosci. 80, 41-47 (2001). 
19. Julien, C. M., Massot, M. \& Poinsignon, C. Lattice vibrations of manganese oxides: Part I. Periodic structures. Spectrochim. Acta - Part A Mol. Biomol. Spectrosc. 60, 689700 (2004).

20. Das, S. \& Hendry, M. J. Application of Raman spectroscopy to identify iron minerals commonly found in mine wastes. Chem. Geol. 290, 101-108 (2011).

21. Shikazono, N. Precipitation mechanisms of barite in sulfate-sulfide deposits in back-arc basins. Geochim. Cosmochim. Acta 58, 2203-2213 (1994).

22. Shikazono, N., Kawabe, H. \& Ogawa, Y. Interpretation of Mineral Zoning in Submarine Hydrothermal Ore Deposits in Terms of Coupled Fluid Flow-Precipitation Kinetics Model. Resour. Geol. 62, 352-368 (2012).

23. Ulrich, M. R. \& Bodnar, R. J. Systematics of stretching of fluid inclusions II: barite at 1 atm confining pressure. Econ. Geol. 83, 1037-1046 (1988).

24. Pagel, M. et al. Thermal history constraints from studies of organic matter, clay minerals, fluid inclusions, and apatite fission tracks at the Ardeche Paleo-Margin (BA1 drill hole, GPF program), France. J. Sediment. Res. 67, 235-245 (1997).

25. Safina, N. P. et al. Barite from the Saf'yanovka VMS deposit (Central Urals) and Semenov-1 and Semenov-3 hydrothermal sulfide fields (Mid-Atlantic Ridge): a comparative analysis of formation conditions. Miner. Depos. 51, 491-507 (2016).

26. Leach, D. L. Nature of mineralizing fluids in the barite deposits of central and southeast Missouri. Econ. Geol. 75, 1168-1180 (1980).

27. Buchanan, L. J., Vivo, B., Kramer, A. K. \& Lima, A. Fluid inclusion study of the Fiumarella barite deposit (Catanzaro- S. Italy). Miner. Depos. 16, 215-226 (1981).

28. Lécuyer, C. et al. Phase separation and fluid mixing in subseafloor back arc hydrothermal systems: A microthermometric and oxygen isotope study of fluid inclusions in the barite-sulfide chimneys of the Lau Basin. J. Geophys. Res. Solid Earth 104, 17911-17927 (1999).

29. Kusakabe, M. \& Chiba, H. Oxygen isotope geothermometry applicable to sulphate minerals from the Kuroko Deposits. Min. Geol. 29, 257-264 (1979).

30. Harzer, D. Sauerstoffisotopenuntersuchungen an varistischen und postvaristischen Lagerstätten Sachsens und Thüringens. (Freib. Forsch., 1967).

31. Canfield, D. E. Biogeochemistry of sulfur isotopes. in Reviews in Mineralogy and Geochemistry 43, 607-636 (2001).

32. Seal, R. R. Sulfur isotope geochemistry of sulfide minerals. in Reviews in Mineralogy and Geochemistry 61, 633-677 (2006). 
33. Alling, V., Humborg, C., Mörth, C. M., Rahm, L. \& Pollehne, F. Tracing terrestrial organic matter by $\delta 34 \mathrm{~S}$ and $\delta 13 \mathrm{C}$ signatures in a subarctic estuary. Limnol. Oceanogr. 53, 2594-2602 (2008).

34. Anderson, T. F. \& Pratt, L. M. Isotopic evidence for the origin of organic sulfur and elemental sulfur in marine sediments. in Geochemical Transformations of Sedimentary Sulfur (eds. Vairavamurthy, M.A. \& Schoonen, M. A. A.) 378-396 (American Chemical Society, 1995).

35. Claypool, G. E., Holser, W. T., Kaplan, I. R., Sakai, H. \& Zak, I. The age curves of sulfur and oxygen isotopes in marine sulfate and their mutual interpretation. Chem. Geol. 28, 199-260 (1980).

36. Jurković, I., Garašić, V. \& Hrvatović, H. Geochemical characteristics of barite occurrences in the Palaeozoic complex of South-eastern Bosnia and their relationship to the barite deposits of the Mid-Bosnian Schist Mountains. Geol. Croat. 63, 241-258 (2010).

37. Krouse, H. R. \& Grinenko, V. A. Stable Isotopes, Natural and Anthropogenic Sulphur in the Environment. (Wiley, 1991).

38. Fritz, P. \& Fontes, J. C. Handbook of Environmental Isotope Geochemistry. The Terrestrial Environment. (Elsevier, 1980). doi:10.1016/C2009-0-15467-3

39. Taylor, H. P. Water/rock interactions and the origin of $\mathrm{H} 2 \mathrm{O}$ in granitic batholiths. $J$. Geol. Soc. London. 133, 509-558 (1977).

40. Révész, K. M. \& Landwehr, J. M. $\delta 13 \mathrm{C}$ and $818 \mathrm{O}$ isotopic composition of $\mathrm{CaCO} 3$ measured by continuous flow isotope ratio mass spectrometry: Statistical evaluation and verification by application to Devils Hole core DH-11 calcite. Rapid Commun. Mass Spectrom. 16, 2102-2114 (2002).

41. Gaškov, M., Sepp, H., Pani, T., Paiste, P. \& Kirsimäe, K. Barite mineralization in Kalana speleothems, Central Estonia: Sr, S and O isotope characterization. Est. J. Earth Sci. 66, 130-141 (2017).

42. Wilkinson, J. J. Fluid Inclusions in Hydrothermal Ore Deposits. Lithos 55, 229-272 (2001).

43. Hałas, S. \& Szaran, J. Improved thermal decomposition of sulfates to SO2 and mass spectrometric determination of $\delta 34$ S of IAEA SO-5, IAEA SO-6 and NBS-127 sulfate standards. Rapid Commun. Mass Spectrom. 15, 1618-1620 (2001).

44. Hałas, S. \& Szaran, J. Use of Cu2O-NaPO3 mixtures for SO2 extraction from BaSO4 for sulphur isotope analysis. Isotopes Environ. Health Stud. 40, 229-231 (2004). 
45. Mizutani, Y. An improvement in the carbon reduction method for the oxygen isotopic analysis of sulfates. Geochem. J. 5, 69-77 (1971).

46. Hałas, S., Szaran, J., Czarnacki, M. \& Tanweer, A. Refinements in BaSO 4 to CO2 Preparation and $\delta 180$ Calibration of the Sulfate Reference. Geostand. geoanalytical Res. 31, 61-68 (2007).

47. McCrea, J. M. On the isotopic geochemistry of carbonates and a paleotemperature scale. J. Chem. Phys. 18, 849-857 (1950).

48. Smith, J. W. \& Batts, B. D. The distribution and isotopic composition of sulfur in coal. Geochim. Cosmochim. Acta 38, 121-133 (1974).

49. Rees C. E., Jenkins, W. J. \& Monster, J. The sulphur isotopic composition. Geochim. Cosmochim. Acta 42, 377-381 (1978).

50. Valley, J. W. Stable isotope geochemistry of metamorphic rocks. Rev. Mineral. Geochemistry 16, 445-489 (1986).

51. Thode, H.G. Sulphur isotopes in nature and the environment: an overview. in Stable isotopes: natural and anthropogenic sulphur in the environment (eds. Krouse, H. R. \& Grinenko, V. A.) 15, 126-132 (John Wiley \& Sons Ltd, 1991).

52. Trumbore, S. E. \& Druffel, E. R. M. Carbon isotopes for characterizing sources and turnover of non-living organic matter. in Role of Non-Living Organic Matter in the Earth's Carbon Cycle (eds. Zepp, R. G. \& Sonntag, C.) (John Wiley \& Sons Ltd, 1995).

53. Hannan, K. Sulfur isotopes in geochemistry. in Geochemistry. Encyclopedia of Earth Science (Springer, 1998). doi:10.1007/1-4020-4496-8_309

54. Luhr, J. F. \& Logan, M. A. V. Sulfur isotope systematics of the 1982 El Chichón trachyandesite: An ion microprobe study. Geochim. Cosmochim. Acta 66, 3303-3316 (2002).

55. Yurimoto, H. Oxygen Isotopes. in Encyclopedia of Geochemistry. Encyclopedia of Earth Sciences Series (ed. White, W.) (Spinger, 2018).

56. Hoefs, J. Stable Isotope Geochemistry. (Spinger Verlag, 2009). doi:10.1007/978-3-54070708-0

\section{Figure captions:}

Tab.1. Characteristics of fluid inclusions in barite from Jebel Ouichane. Symbols: SD standard deviation, C.V. - coefficient of variation $=($ SD/average $) \times 100$. 
Tab.2. Chemical composition of barite in weight \% (wt. \%), measured by Energy-dispersive $\mu \mathrm{X}$-ray Fluorescence Spectrometry, recalculated to fixed $\mathrm{SO}_{3}$ content and a total of 100 (wt. \%). $\mathrm{Al}_{2} \mathrm{O}_{3}, \mathrm{MgO}, \mathrm{MnO}$, and $\mathrm{Na}_{2} \mathrm{O}$ contents were below the detection limit. Error is 0.00 for all (in wt. \%, 1 Sigma).

Tab.3. Representative electron microprobe data of barite from Jebel Ouichane.

Fig.1. An example of gem-quality specimens of blue barite from Jebel Ouichane.

Fig.2. Geological map showing main lithologies found in the vicinity of Jebel Quichane area, modified after Bouabdellah et al., ${ }^{13}$.

Fig.3. (A, B) Intergrowths made of siderite (Sd) and hematite (Hem) (central part of the image), surrounded by replacive isometric crystals of hematite (martite) formed after magnetite (Mt); (C, D) Colloform aggregates of hematite accompanied by minor siderite and quartz (Qtz); Note that PX denotes transmitted light mode (with crossed polars) and RL corresponds to the reflected-light mode.

Fig.4. Fluid inclusions assemblages (FIAs) in barite from Jebel Ouichane: A- primary, onephase, liquid inclusions; B - in the centre, big two-phase inclusion with tail showing neckingdown process, surrounded by numerous, small, one-phase inclusions; C- secondary, onephase inclusions arranged perpendicular to the crystal face; D- psudosecondary, one-phase, liquid, inclusions showing characteristic rectangular shapes.

Fig.5. Microphotos of inclusions in calcite: A - well visible crystal growth zones of calcite with abundant solid inclusions in the core, composed of opaque minerals in transmitted light; B - tiny, liquid fluid inclusions (FI) arranged in the groups and solid inclusions (SI) of opaque minerals in transmitted light.

Fig. 6. False-colour elemental distribution maps for Ba, S, Sr, and K obtained by the Energydispersive $\mu \mathrm{X}$-ray Fluorescence Spectrometry of barite crystals (polished section).

Fig.7. Microphotos and Raman spectra collected in the various regions of barite crystal: red and blue lines correspond to spectra collected in microprobe analytical points 14 and 9, 
respectively (vide Tab. 3). The inset shows the variations in the intensity of the Raman bands at 461 and $452 \mathrm{~cm}^{-1}$ recorded for crystal domains slightly differing in $\mathrm{Sr}$ and $\mathrm{Ba}$ content.

Fig.8. Microhoto and Raman spectrum collected for fluid inclusions in barite. Note that all bands correspond to the host mineral.

Fig.9. Microphotos of solid inclusions in calcite (Cal) and their Raman spectra: A - chalcophanite (Cha); B- goethite (Gt).

Fig.10 Distribution of $\delta^{34} \mathrm{~S}(\mathrm{~A}), \delta^{18} \mathrm{O}(\mathrm{B})$, and $\delta^{13} \mathrm{C}(\mathrm{C})$ in barite and calcite from Jebel Quichane in relation to various geological reservoirs; data after ${ }^{39,48-56 .}$

Fig.11. Histogram of homogenization temperatures $\left({ }^{\circ} \mathrm{C}\right)$ obtained for fluid inclusions hosted in barite from Jebel Ouichane. 
Tab.1.

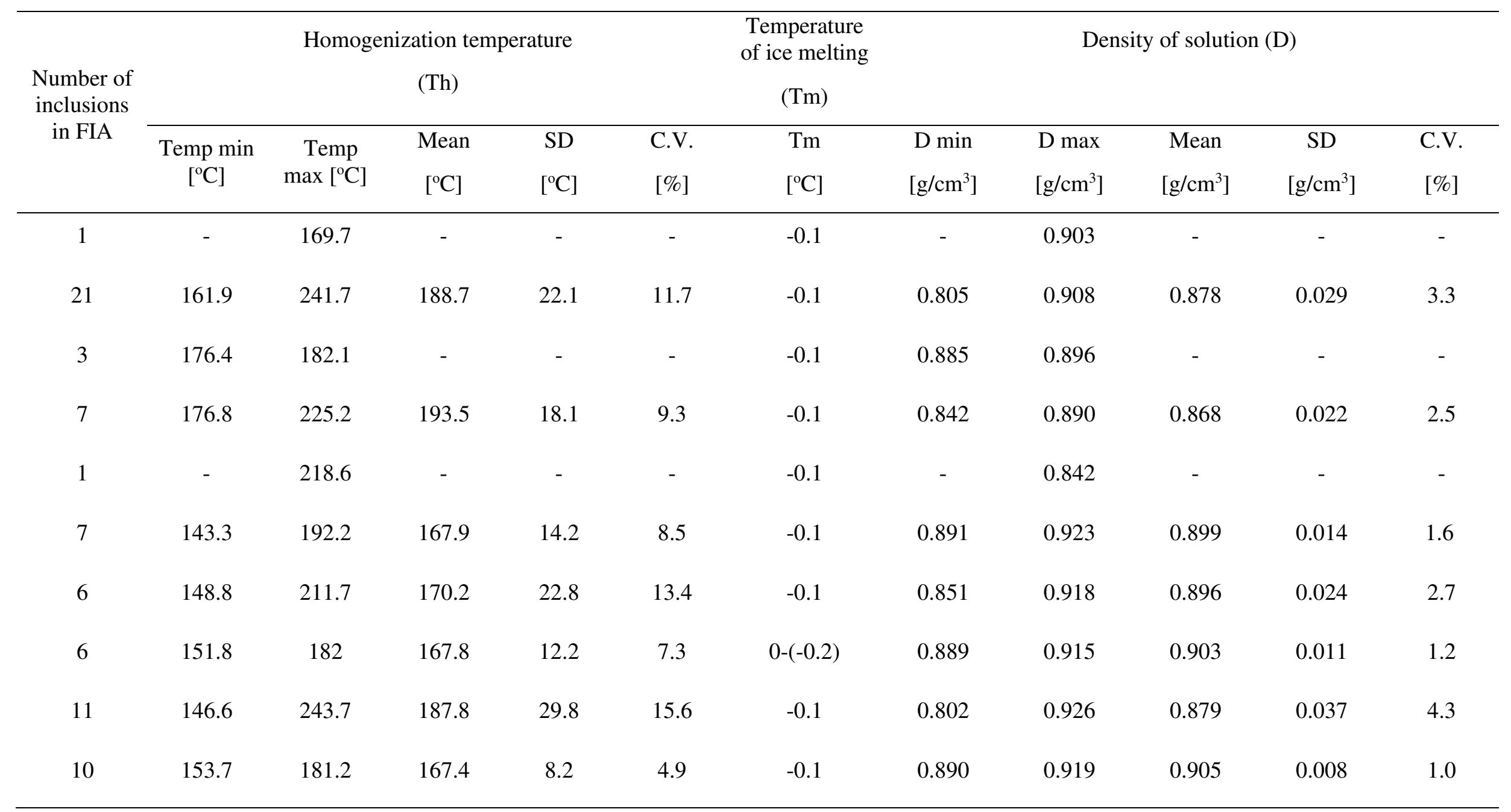


Tab.2.

\begin{tabular}{cccccccccc}
\hline $\begin{array}{l}\text { Oxide content } \\
\text { (wt. \%) }\end{array}$ & $\mathrm{BaO}$ & $\mathrm{CaO}$ & $\mathrm{CuO}$ & $\mathrm{FeO}$ & $\mathrm{K}_{2} \mathrm{O}$ & $\mathrm{SO}_{3}$ & $\mathrm{SrO}$ & $\mathrm{ZnO}$ & Total \\
\hline Analysis & & & & & & & & & \\
1 & 61.59 & 0.33 & 0.00 & 0.00 & 0.00 & 34.30 & 1.00 & 0.04 & 100.00 \\
2 & 59.43 & 0.23 & 0.02 & 0.00 & 0.44 & 34.30 & 0.41 & 0.18 & 100.00 \\
3 & 63.46 & 0.26 & 0.07 & 0.02 & 0.48 & 34.30 & 0.31 & 0.08 & 100.00 \\
4 & 63.09 & 0.00 & 0.05 & 0.07 & 2.39 & 34.30 & 0.91 & 0.04 & 100.00 \\
5 & 63.08 & 0.00 & 0.18 & 0.23 & 0.18 & 34.30 & 0.63 & 0.00 & 100.00 \\
6 & 65.02 & 0.05 & 0.06 & 0.00 & 0.29 & 34.30 & 0.06 & 0.08 & 100.00 \\
7 & 59.29 & 0.00 & 0.10 & 0.00 & 0.00 & 34.30 & 0.51 & 0.16 & 100.00 \\
8 & 62.36 & 0.09 & 0.29 & 0.01 & 0.72 & 34.30 & 0.00 & 0.06 & 100.00 \\
9 & 64.75 & 0.33 & 0.05 & 0.19 & 0.82 & 34.30 & 0.79 & 0.00 & 100.00 \\
10 & 64.73 & 0.00 & 0.28 & 0.00 & 0.30 & 34.30 & 0.41 & 0.08 & 100.00 \\
11 & 59.86 & 0.00 & 0.07 & 0.07 & 0.00 & 34.30 & 0.29 & 0.08 & 100.00 \\
12 & 60.93 & 0.00 & 0.18 & 0.26 & 0.00 & 34.30 & 0.75 & 0.03 & 100.00 \\
13 & 56.74 & 0.00 & 0.10 & 0.19 & 1.13 & 34.30 & 1.06 & 0.19 & 100.00 \\
14 & 62.22 & 0.00 & 0.15 & 0.00 & 0.81 & 34.30 & 0.23 & 0.18 & 100.00 \\
15 & 65.08 & 0.24 & 0.03 & 0.00 & 0.00 & 34.30 & 0.24 & 0.08 & 100.00 \\
\hline Minimum & 56.74 & 0.05 & 0.02 & 0.01 & 0.18 & 34.30 & 0.06 & 0.03 & 100.00 \\
Maximum & 65.08 & 0.33 & 0.29 & 0.26 & 2.39 & 34.30 & 1.06 & 0.19 & 100.00 \\
Average & 62.11 & 0.22 & 0.12 & 0.13 & 0.76 & 34.30 & 0.54 & 0.10 & 100.00
\end{tabular}


Tab.3.

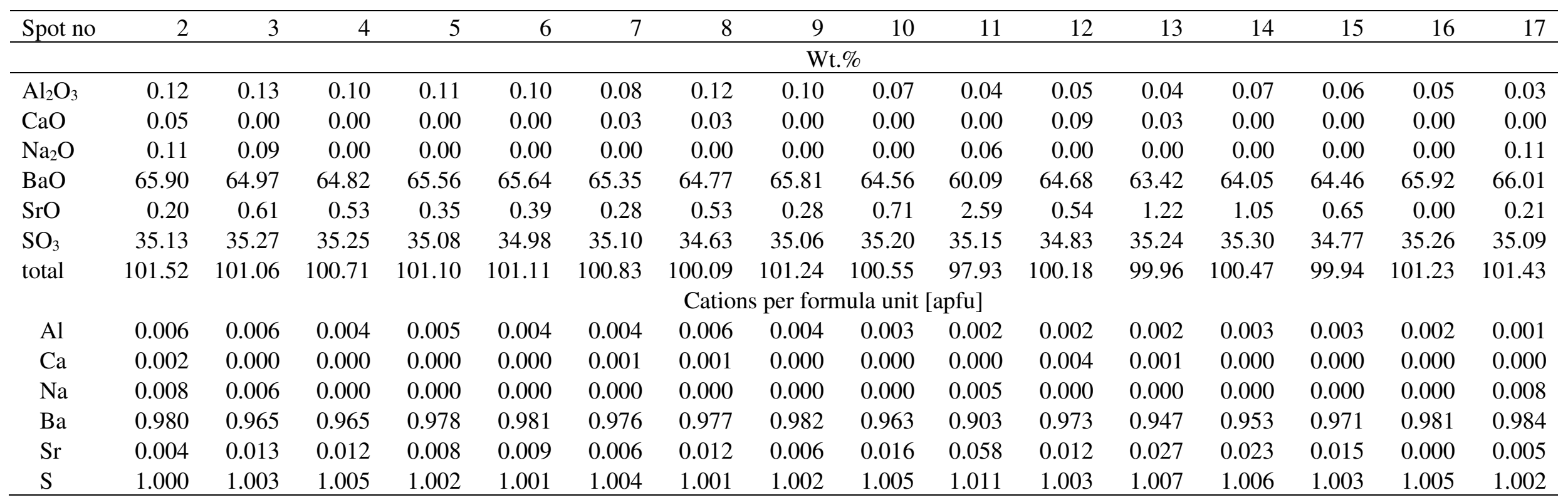


Fig. 1

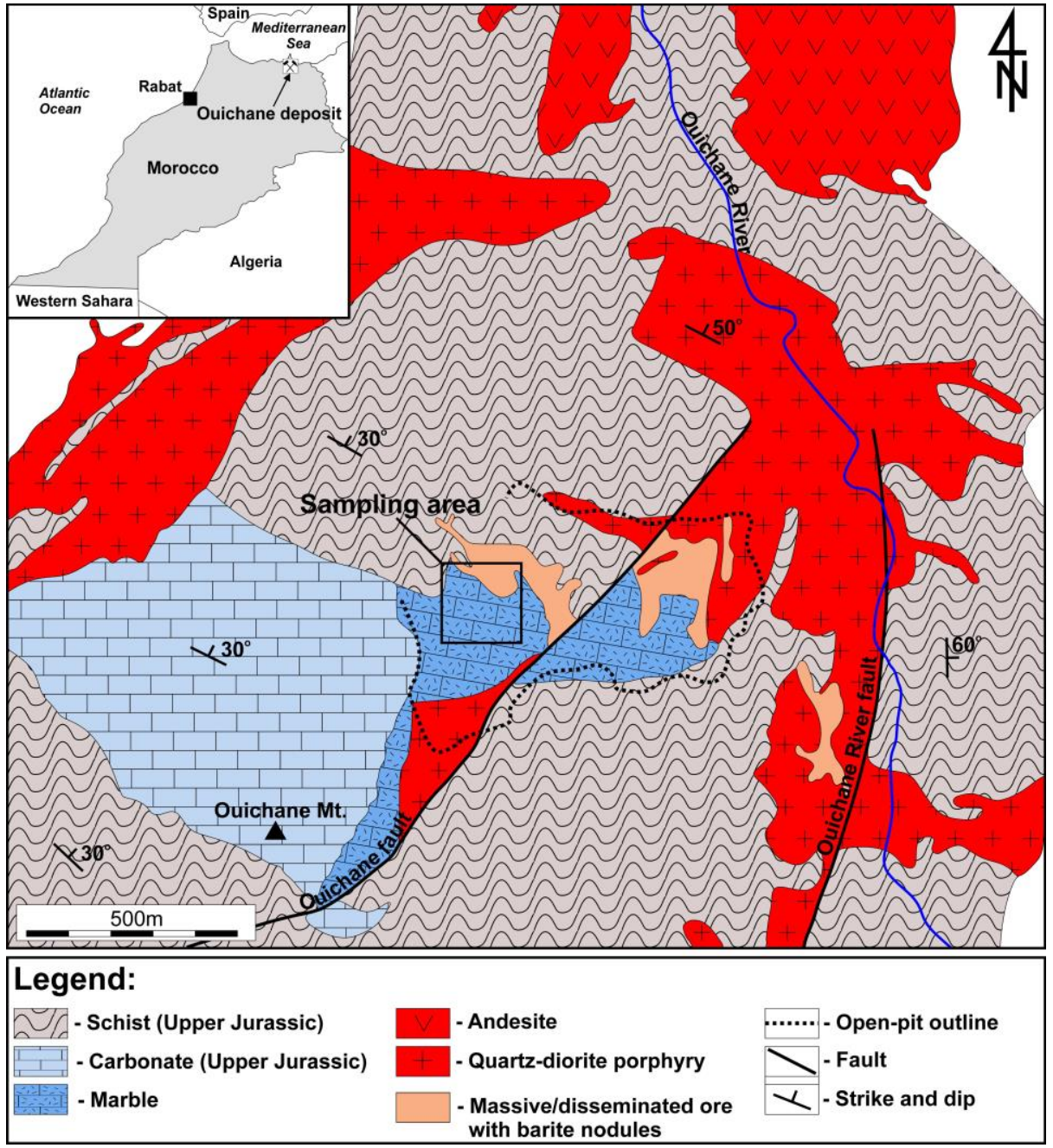

Fig.2.

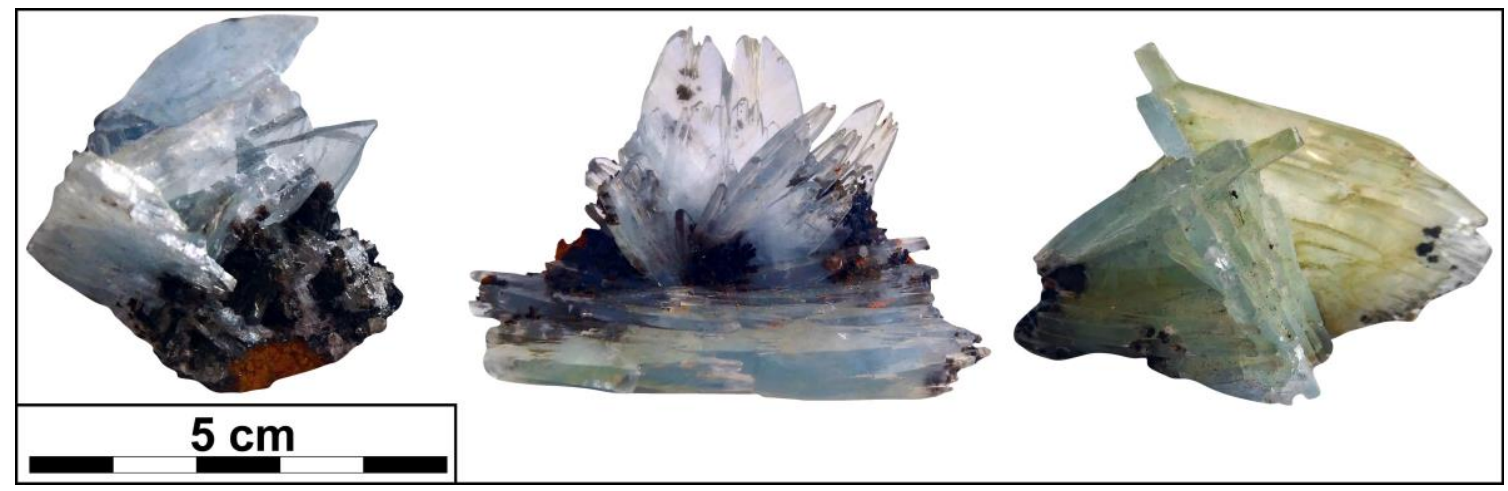


Fig. 3.
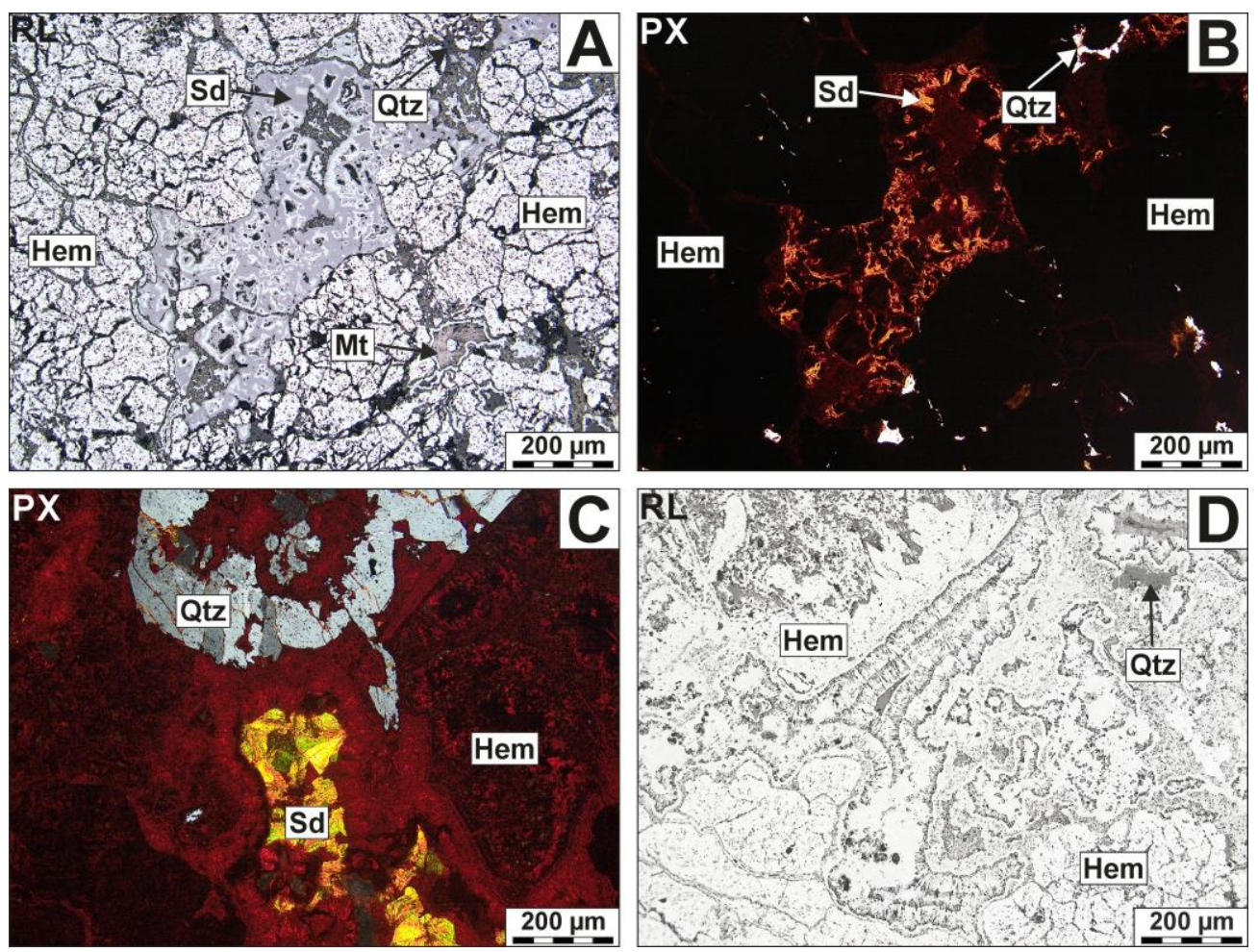

Fig.4.
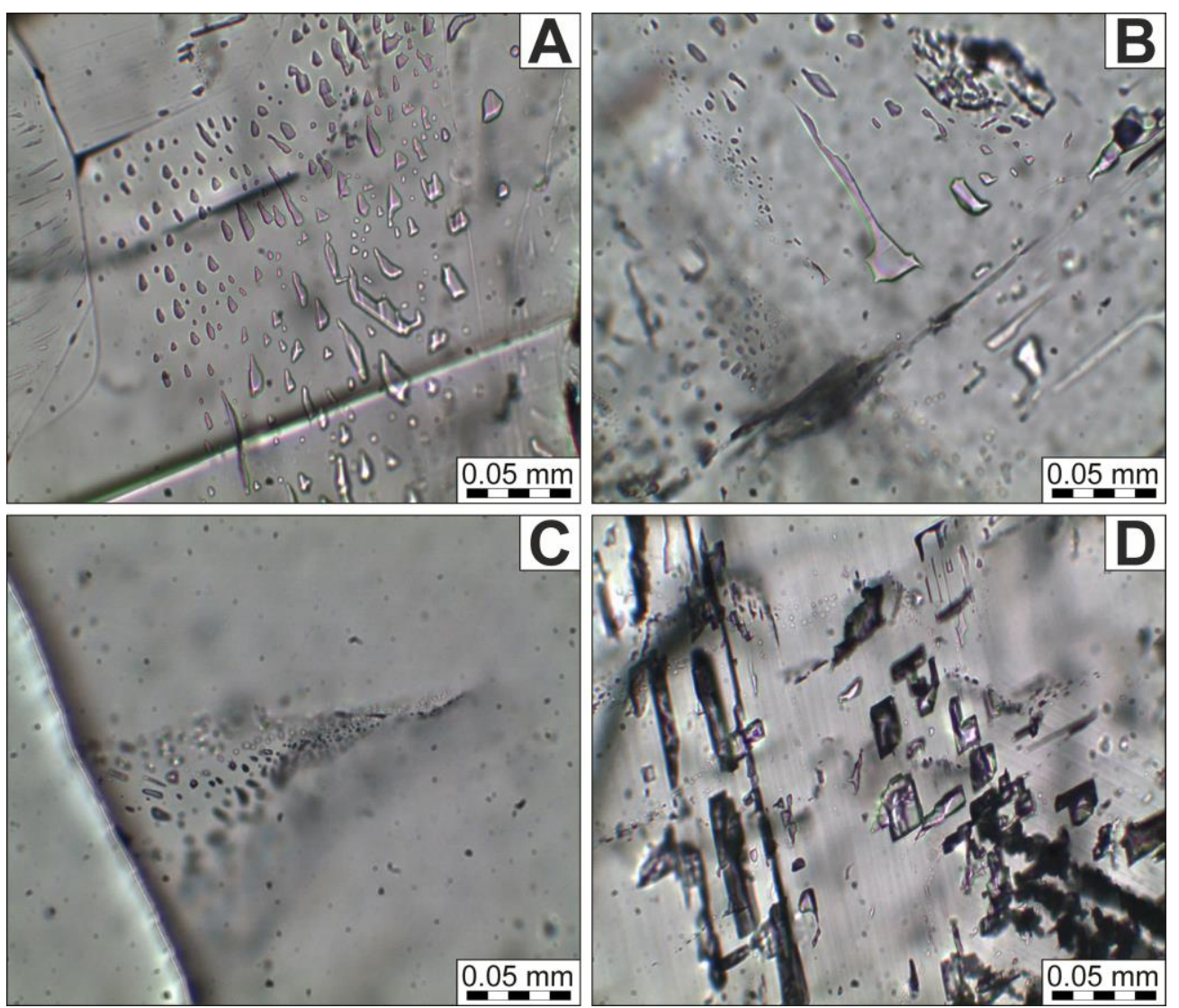
Fig. 5.

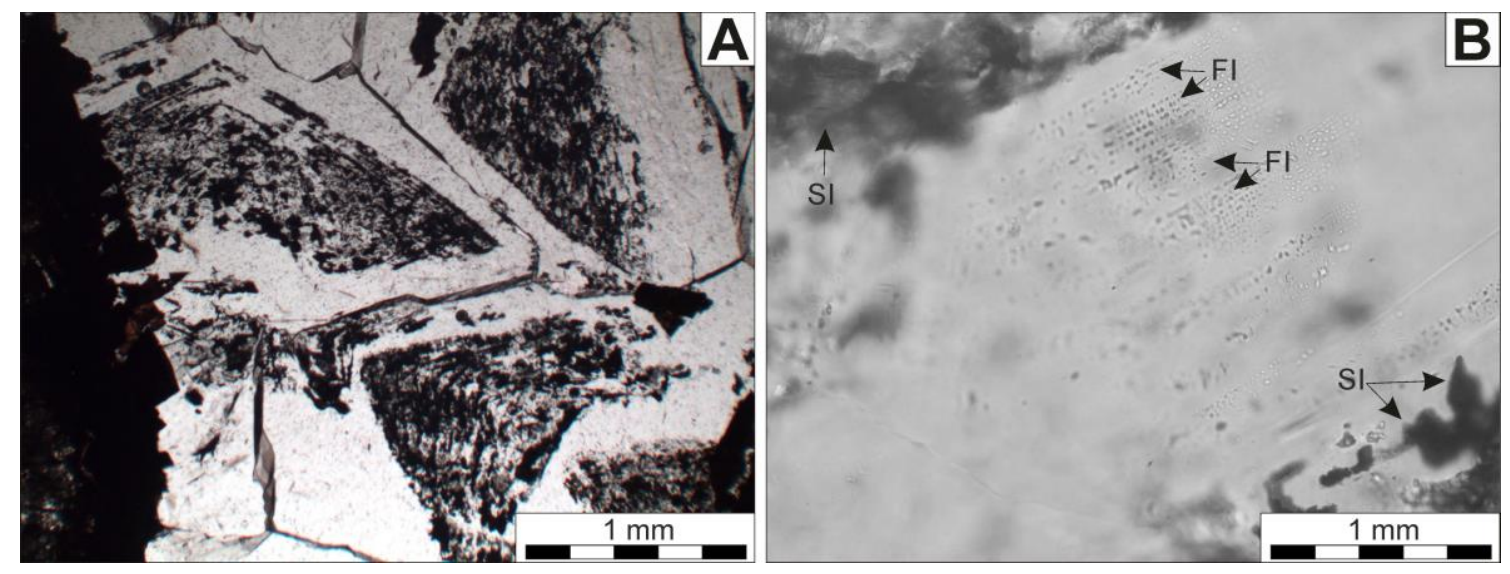

Fig.6.
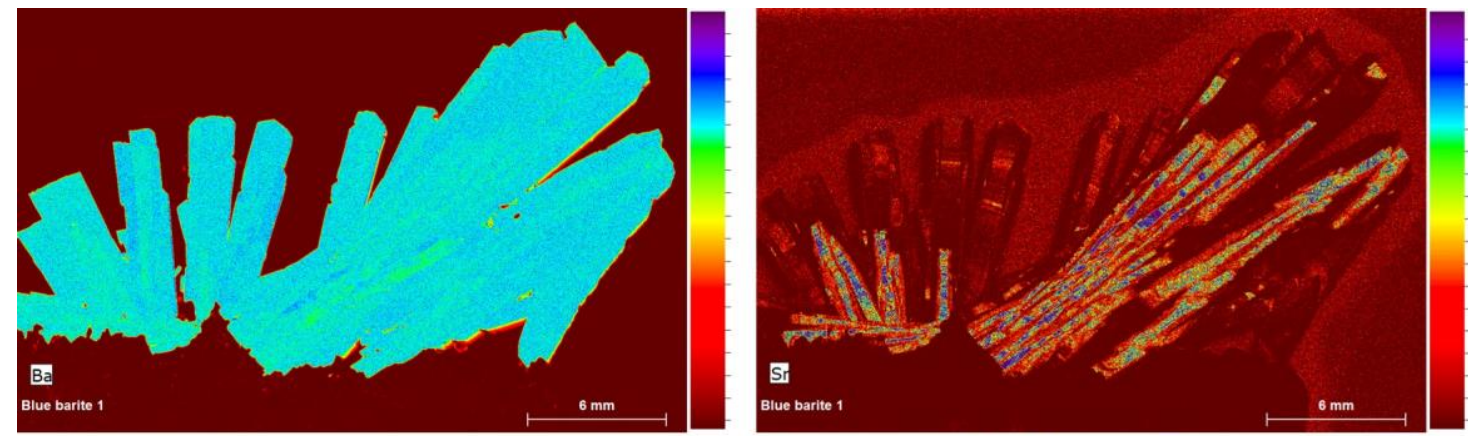

95
91
87
84
80
76
72
68
64
60
56
52
48
44
40
36
33
$<28$
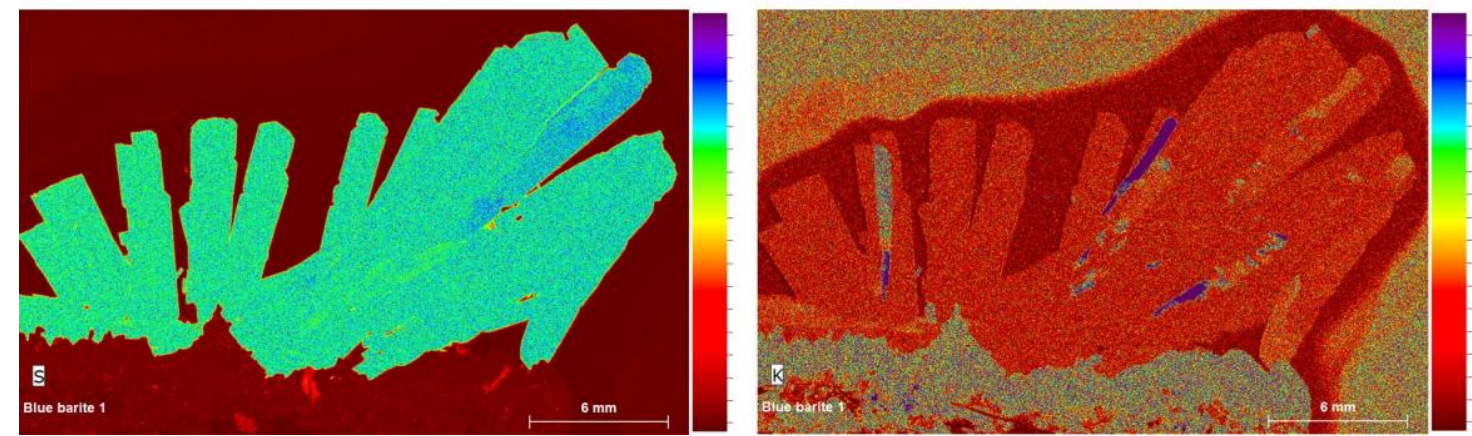

节

${ }_{99} \quad \underline{\Xi}$

${ }_{84} \mathrm{O}$

$78 \frac{0}{10}$

${ }_{52}^{67} \stackrel{00}{.}$

56 51

45 过

${ }_{35}^{40} \Xi$ 
Fig.7.

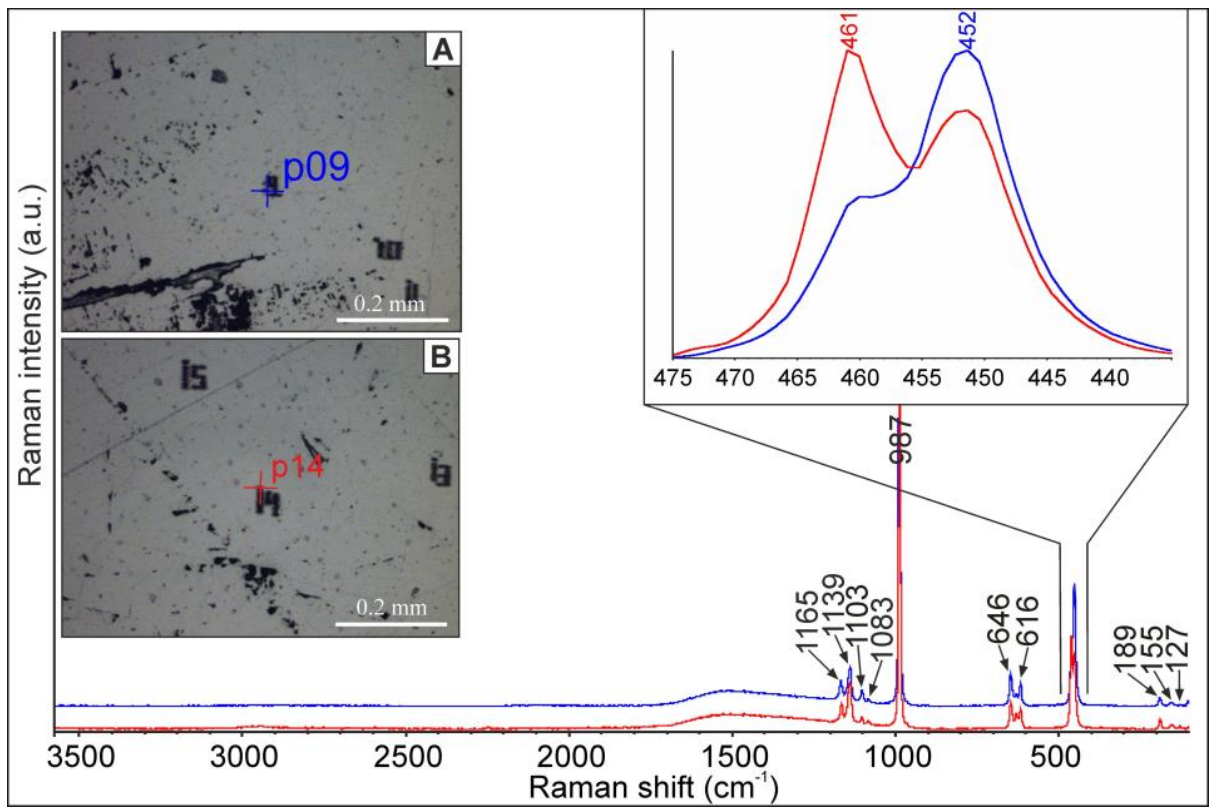

Fig.8

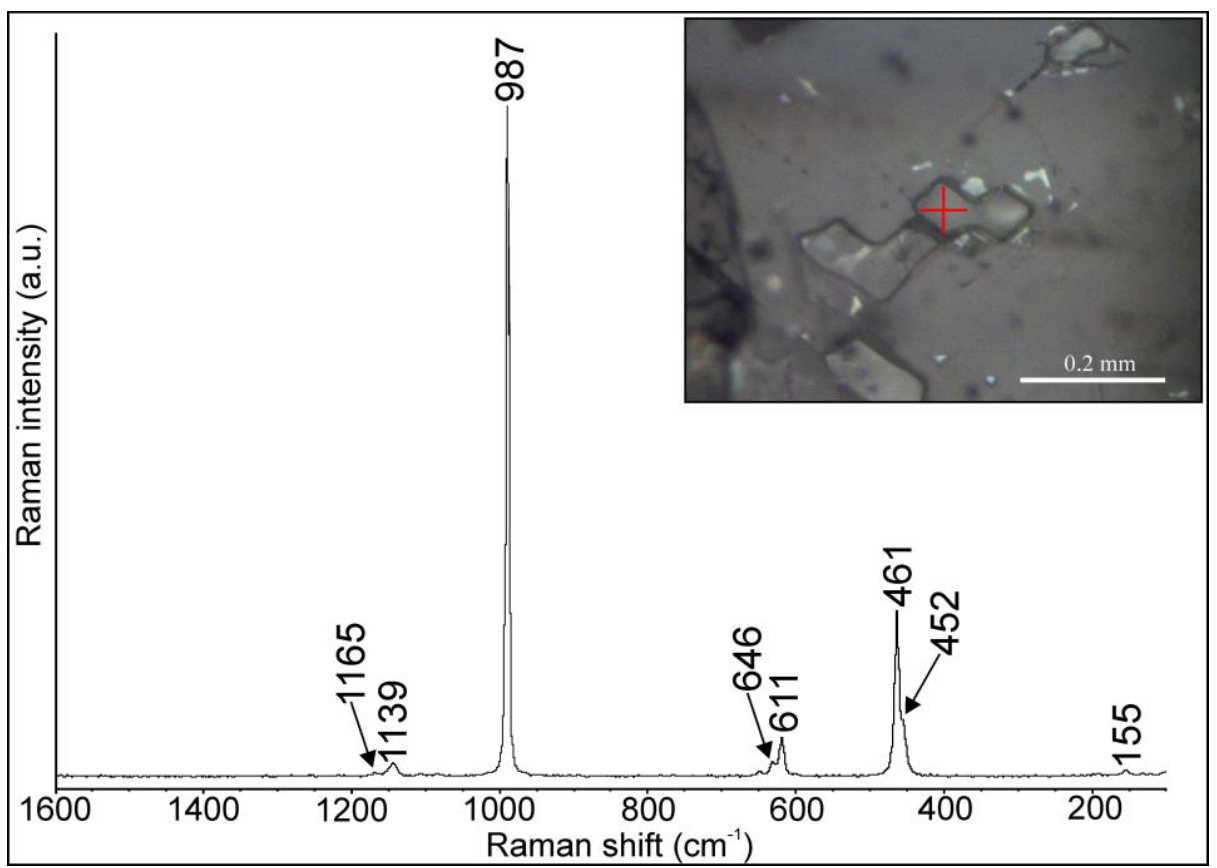


Fig.9.
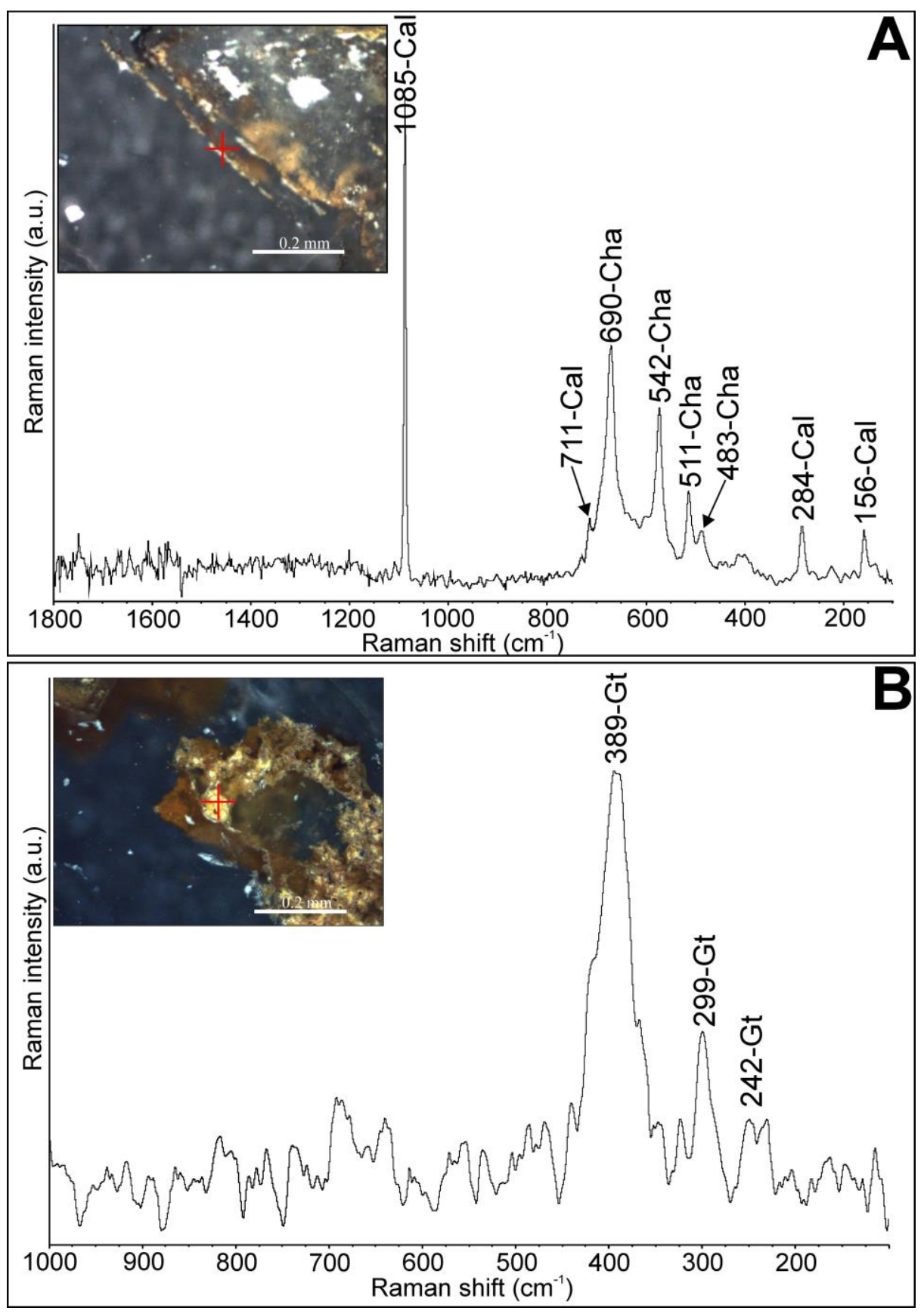
Fig.10
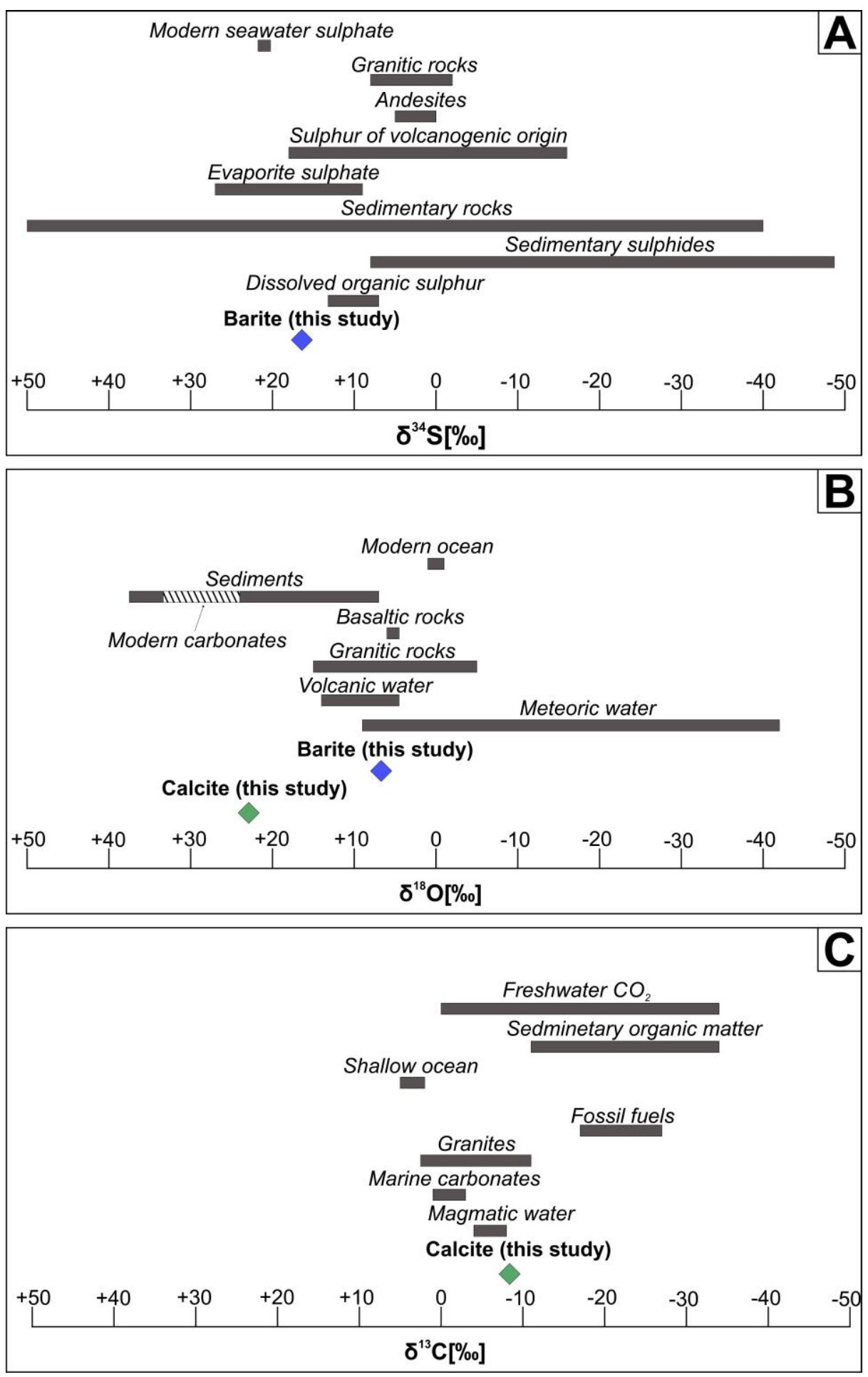
Fig. 11

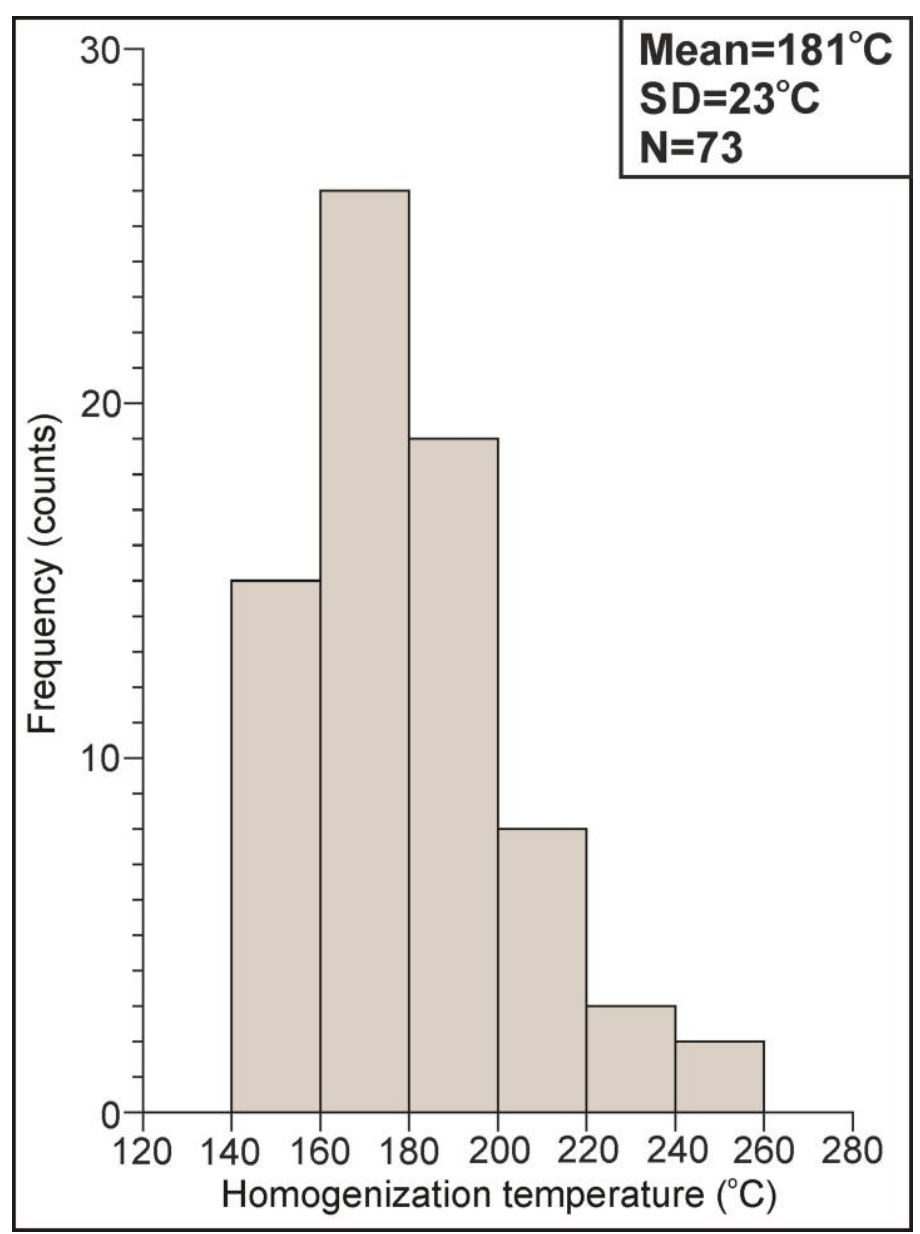




\section{Figures}

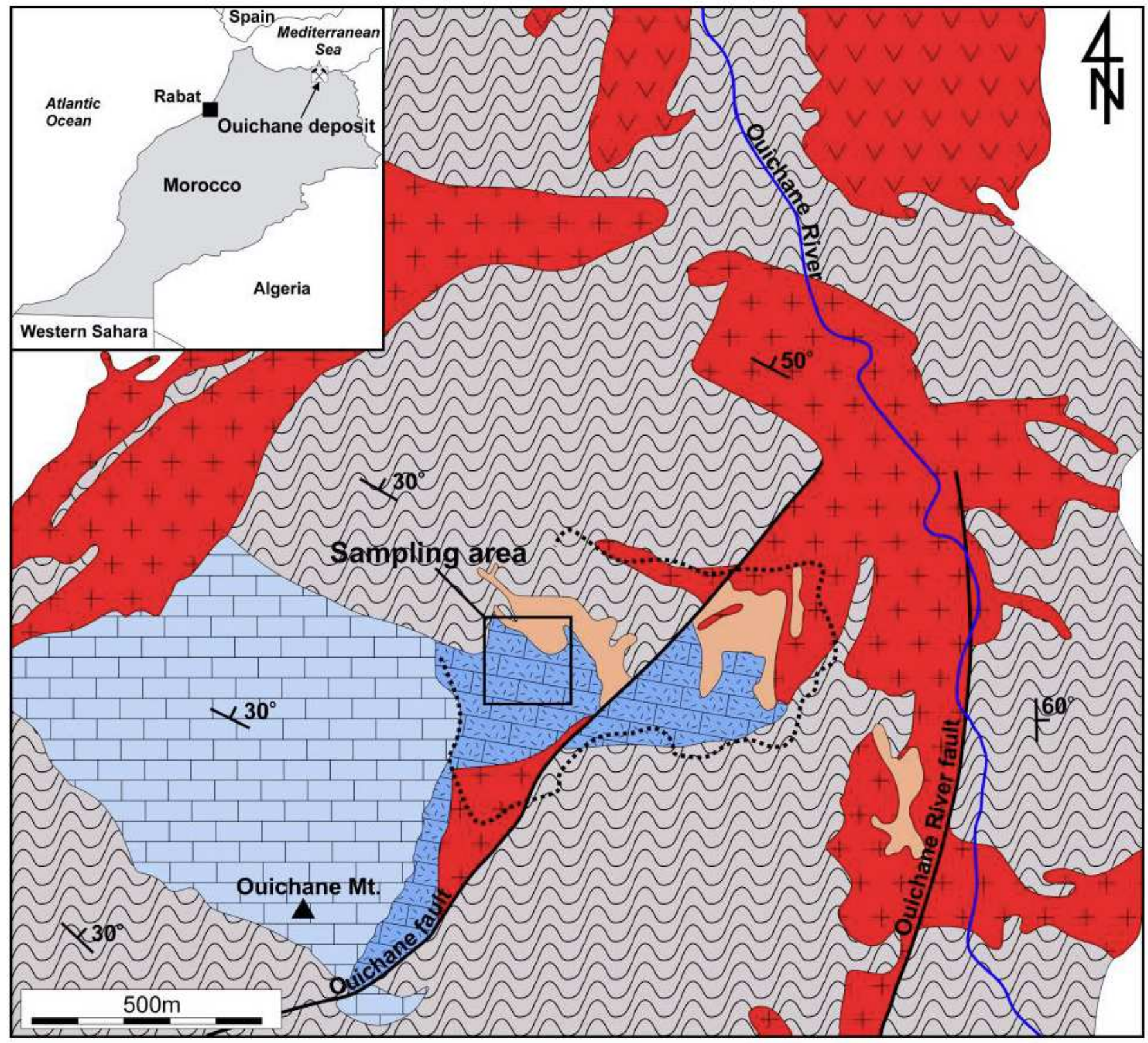

\section{Legend:}

- Carbonate (Upper Jurassic)
- Marble

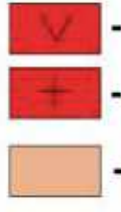

Andesite

- Quartz-diorite porphyry

- Massive/disseminated ore with barite nodules
....... - Open-pit outline

- - Fault
$Y$-Strike and dip

\section{Figure 1}

An example of gem-quality specimens of blue barite from Jebel Ouichane. 


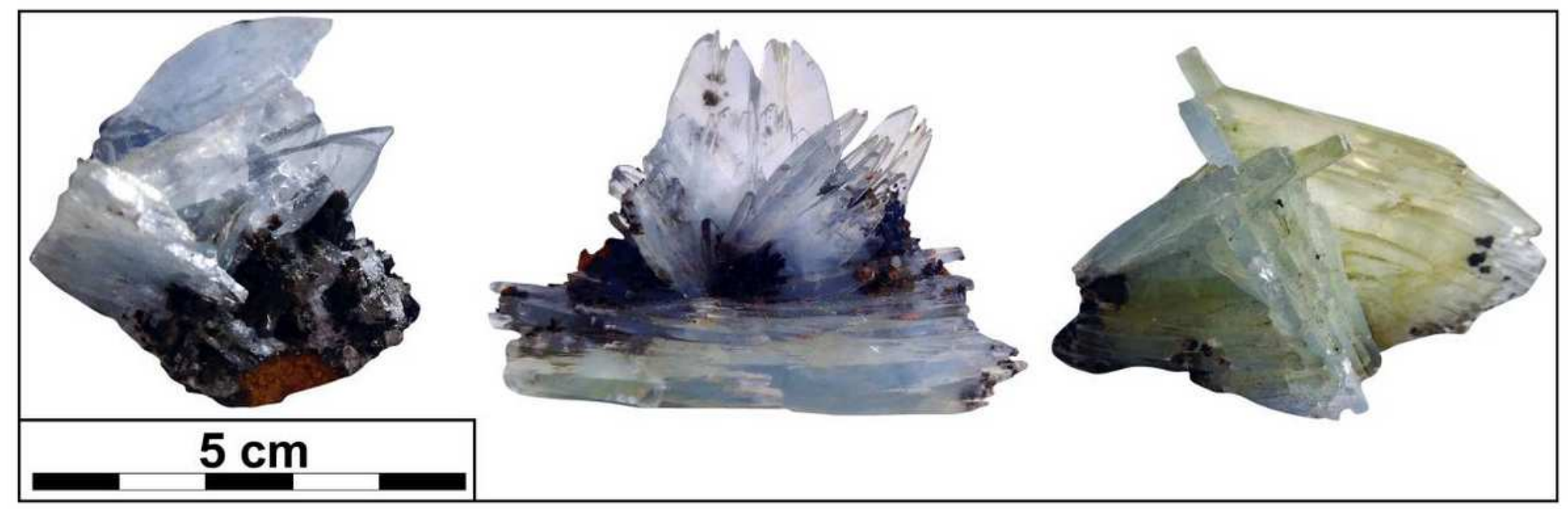

Figure 2

Geological map showing main lithologies found in the vicinity of Jebel Quichane area, modified after Bouabdellah et al., 13.
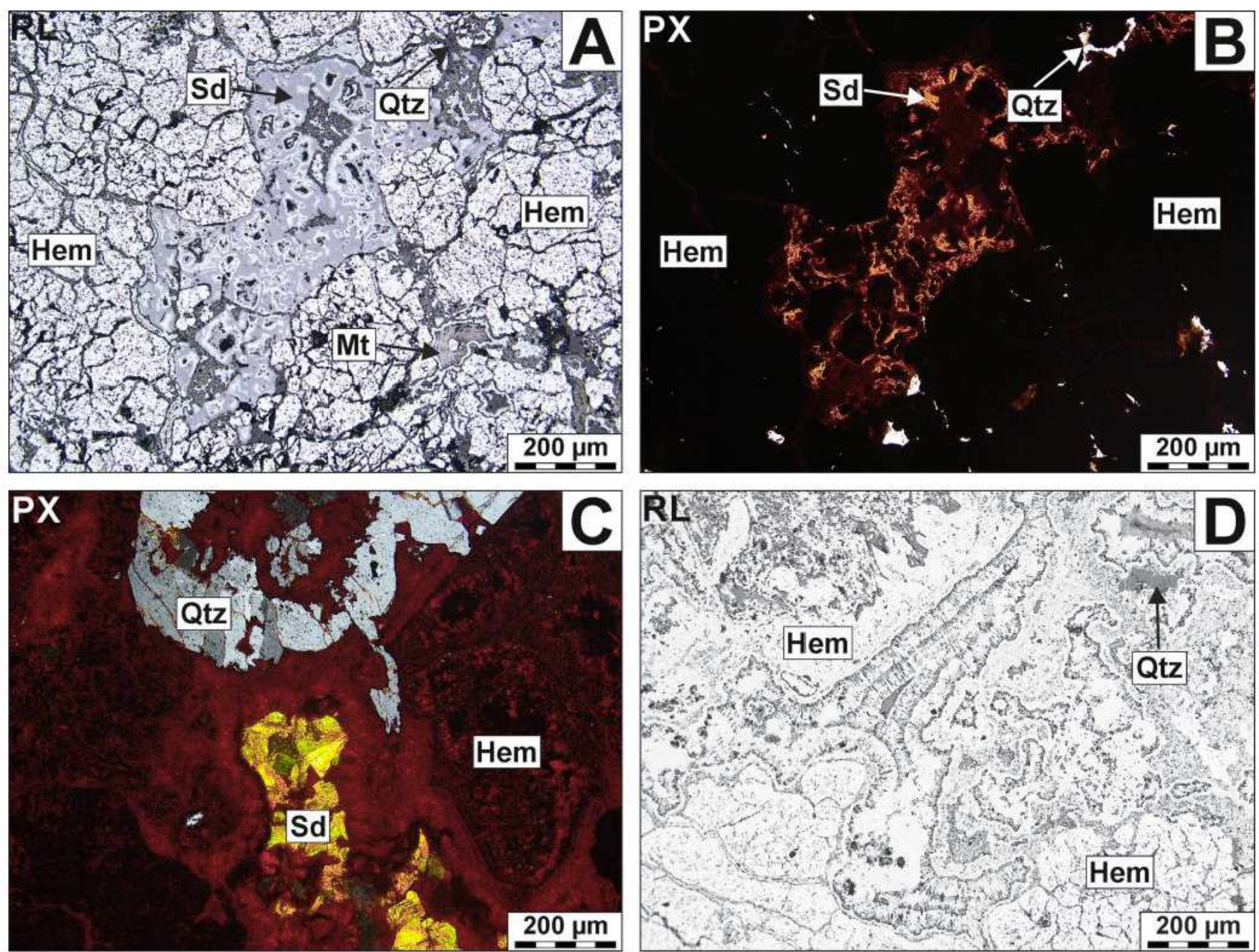


\section{Figure 3}

(A, B) Intergrowths made of siderite (Sd) and hematite (Hem) (central part of the image), surrounded by replacive isometric crystals of hematite (martite) formed after magnetite (Mt); (C, D) Colloform aggregates of hematite accompanied by minor siderite and quartz (Qtz); Note that PX denotes transmitted light mode (with crossed polars) and RL corresponds to the reflected-light mode.
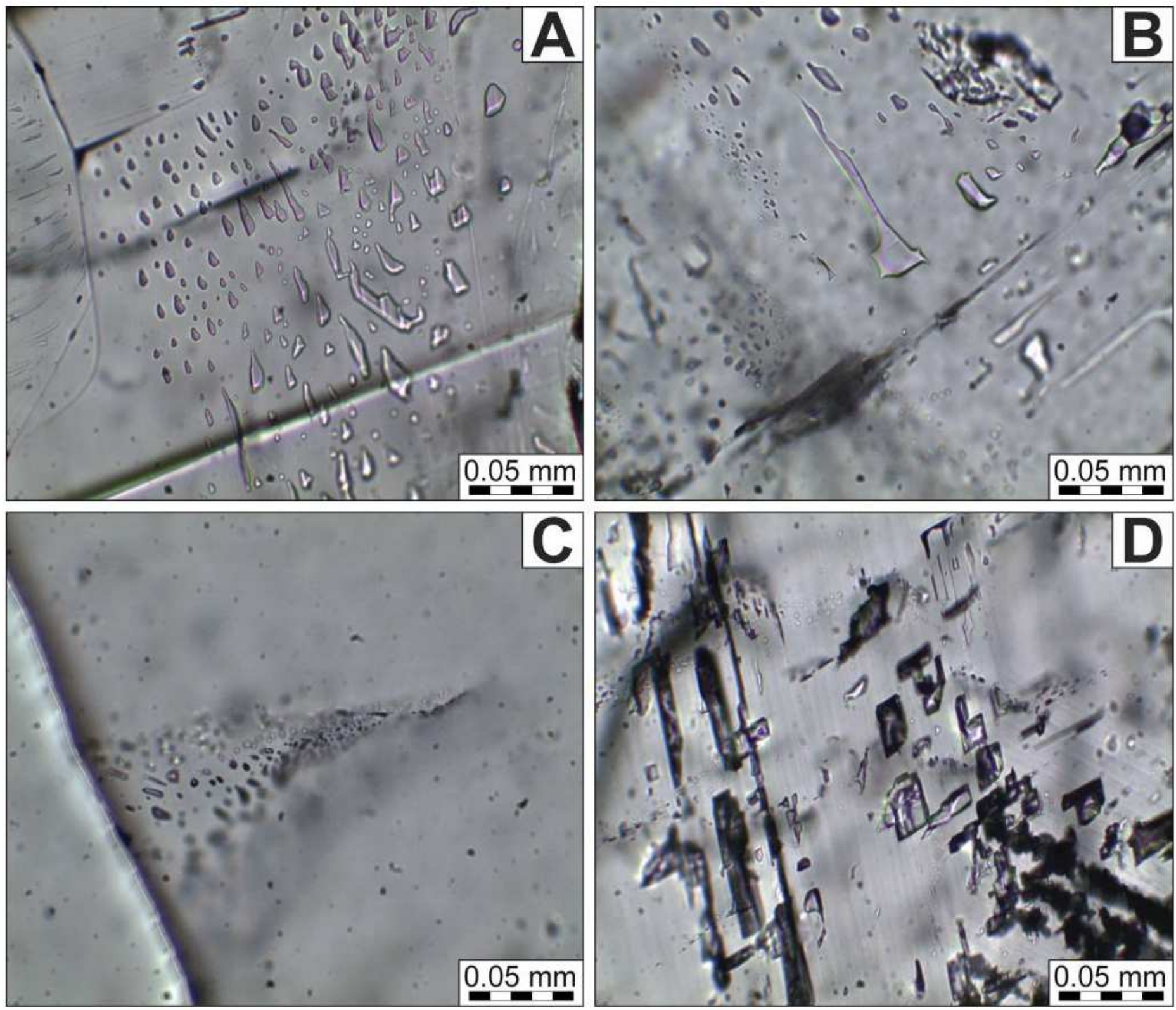

\section{Figure 4}

Fluid inclusions assemblages (FIAs) in barite from Jebel Ouichane: A- primary, one-phase, liquid inclusions; $\mathrm{B}$ - in the centre, big two-phase inclusion with tail showing necking-down process, surrounded by numerous, small, one-phase inclusions; C- secondary, one-phase inclusions arranged perpendicular to 
the crystal face; D- psudosecondary, one-phase, liquid, inclusions showing characteristic rectangular shapes.
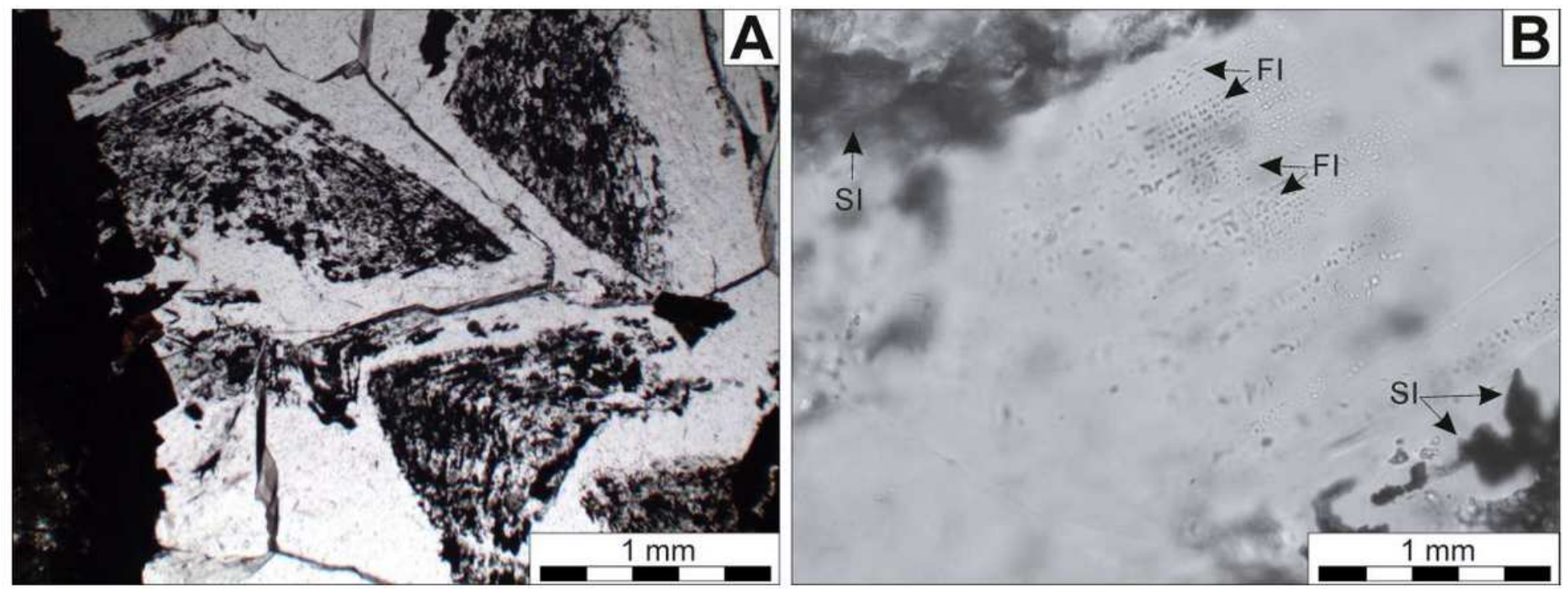

\section{Figure 5}

Microphotos of inclusions in calcite: A - well visible crystal growth zones of calcite with abundant solid inclusions in the core, composed of opaque minerals in transmitted light; B - tiny, liquid fluid inclusions (FI) arranged in the groups and solid inclusions (SI) of opaque minerals in transmitted light.
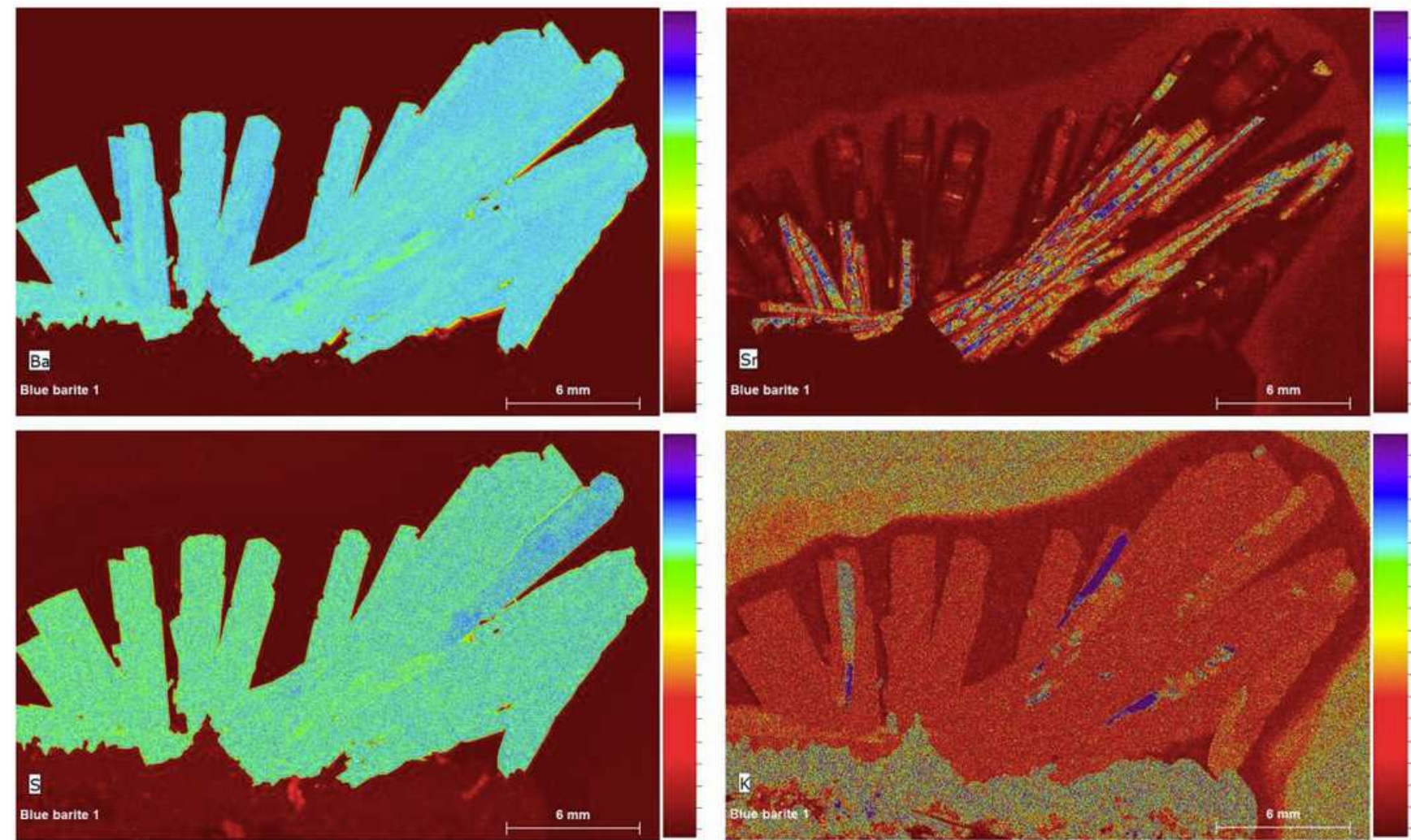
False-colour elemental distribution maps for $\mathrm{Ba}, \mathrm{S}, \mathrm{Sr}$, and K obtained by the Energy-dispersive $\mu \mathrm{X}$-ray Fluorescence Spectrometry of barite crystals (polished section).

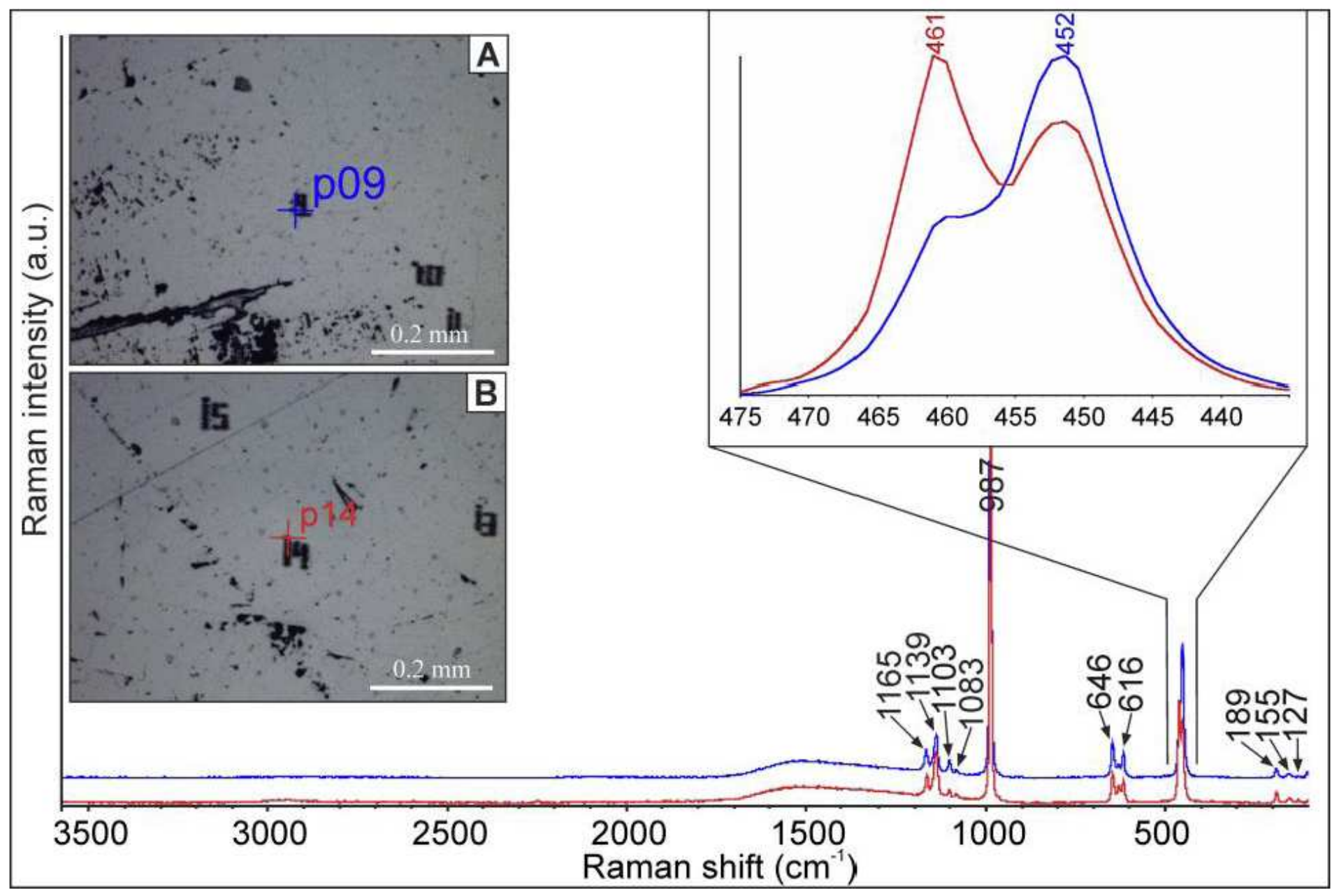

\section{Figure 7}

Microphotos and Raman spectra collected in the various regions of barite crystal: red and blue lines correspond to spectra collected in microprobe analytical points 14 and 9, respectively (vide Tab. 3). The inset shows the variations in the intensity of the Raman bands at 461 and $452 \mathrm{~cm}-1$ recorded for crystal domains slightly differing in $\mathrm{Sr}$ and Ba content. 


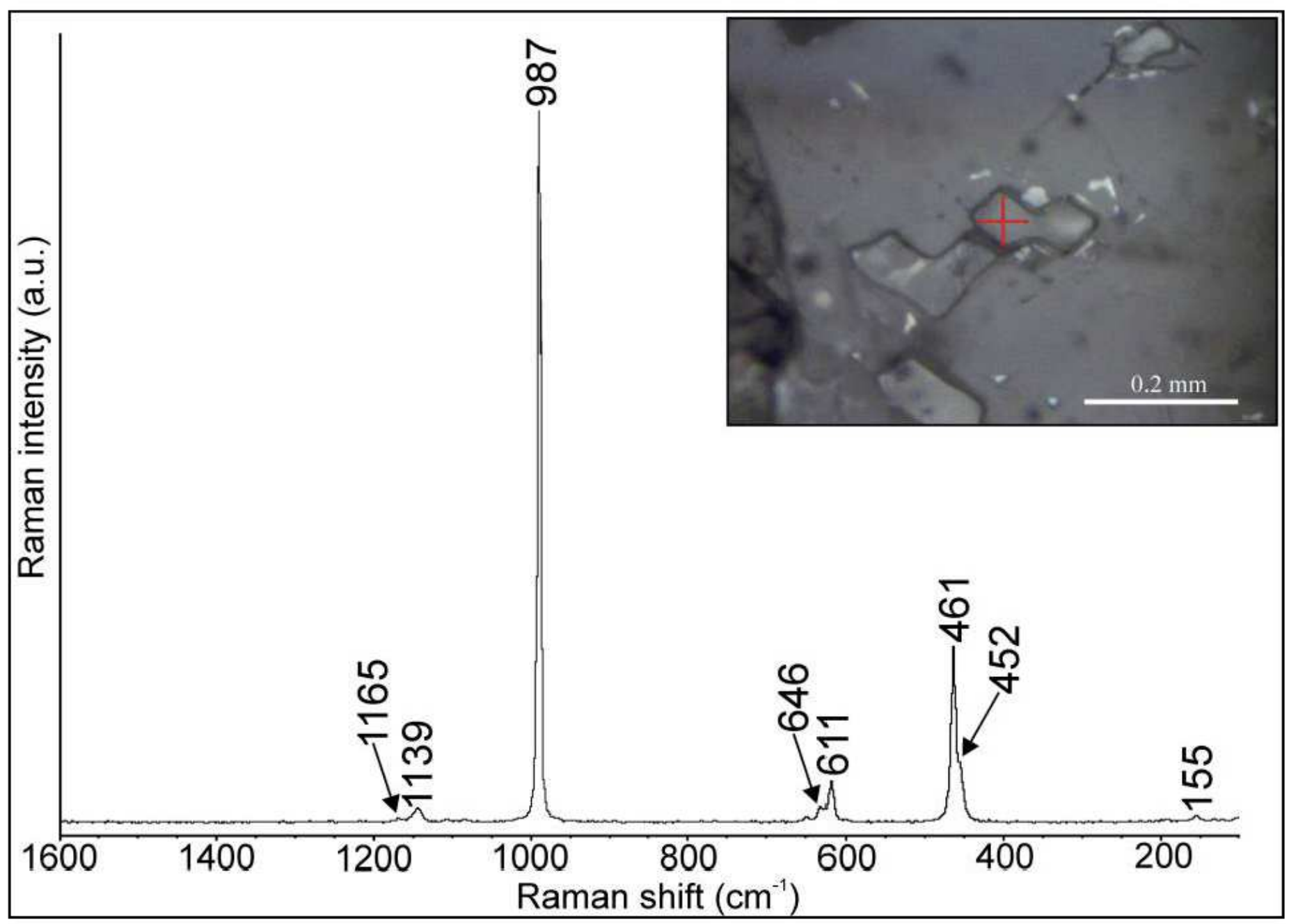

Figure 8

Microhoto and Raman spectrum collected for fluid inclusions in barite. Note that all bands correspond to the host mineral. 

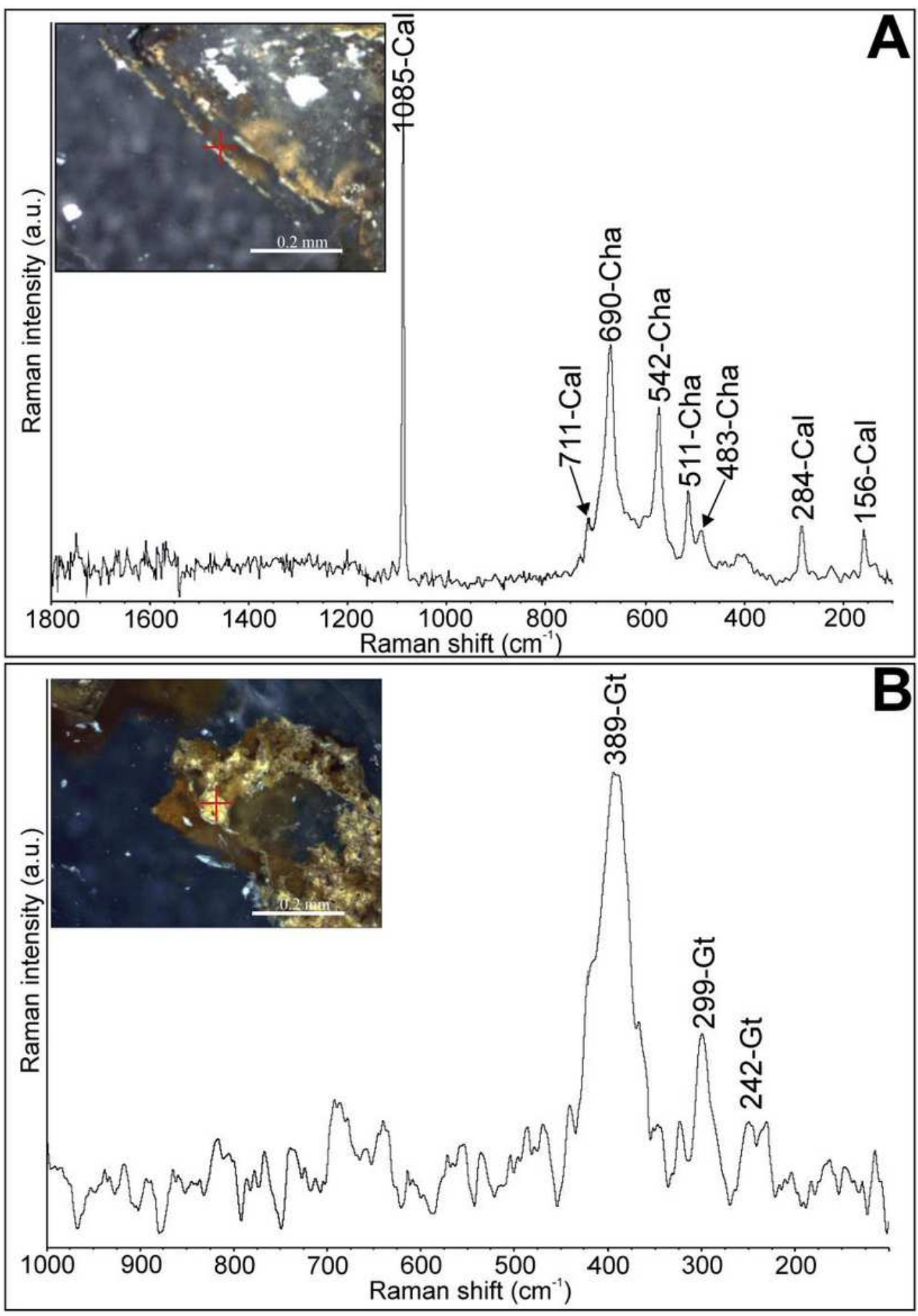

Figure 9

Microphotos of solid inclusions in calcite (Cal) and their Raman spectra: A - chalcophanite (Cha); Bgoethite (Gt). 

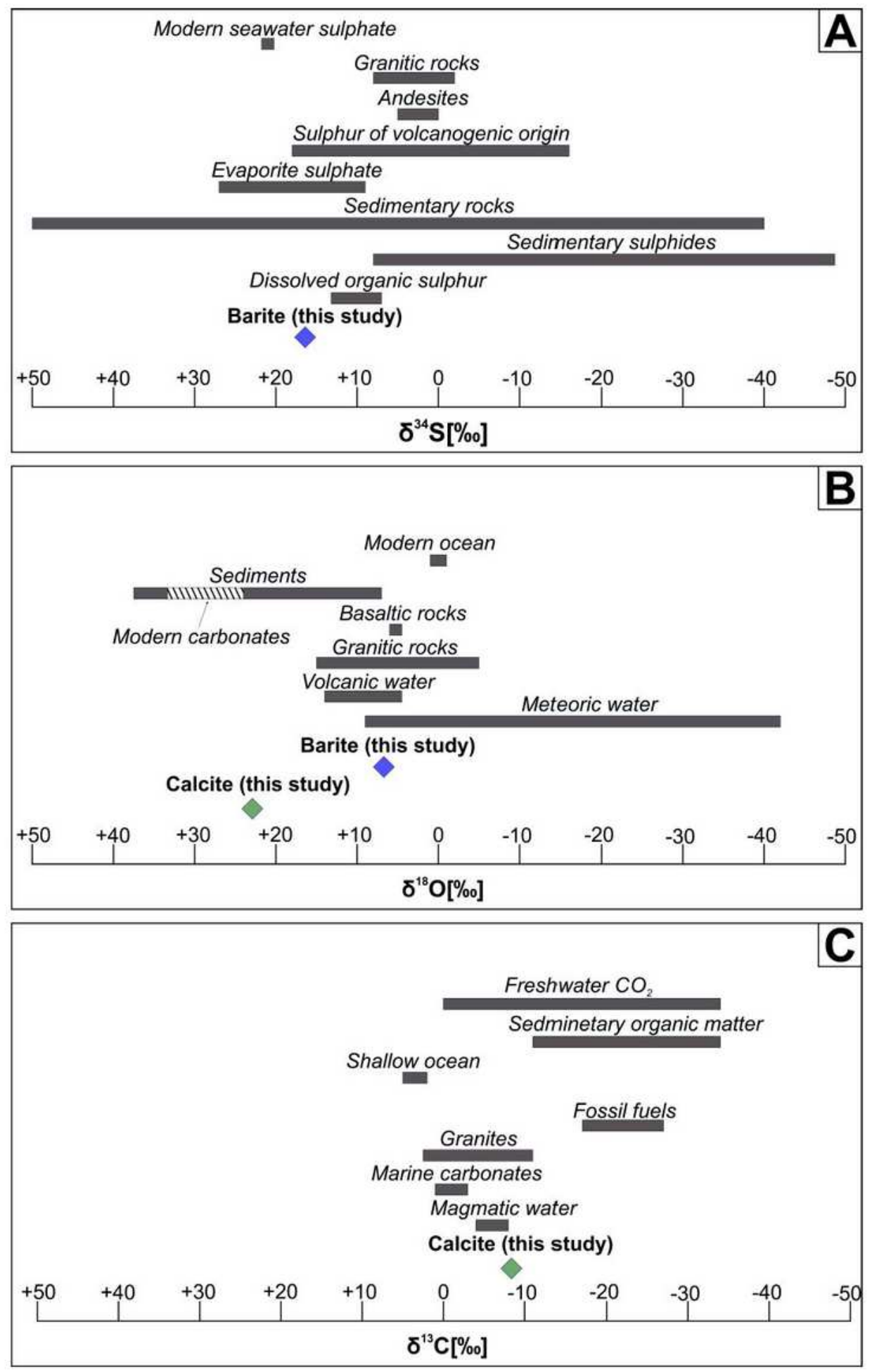

\section{Figure 10}

Distribution of $\delta 34 \mathrm{~S}(\mathrm{~A}), \delta 180(\mathrm{~B})$, and $\delta 13 \mathrm{C}(\mathrm{C})$ in barite and calcite from Jebel Quichane in relation to various geological reservoirs; data after 39,48-56. 


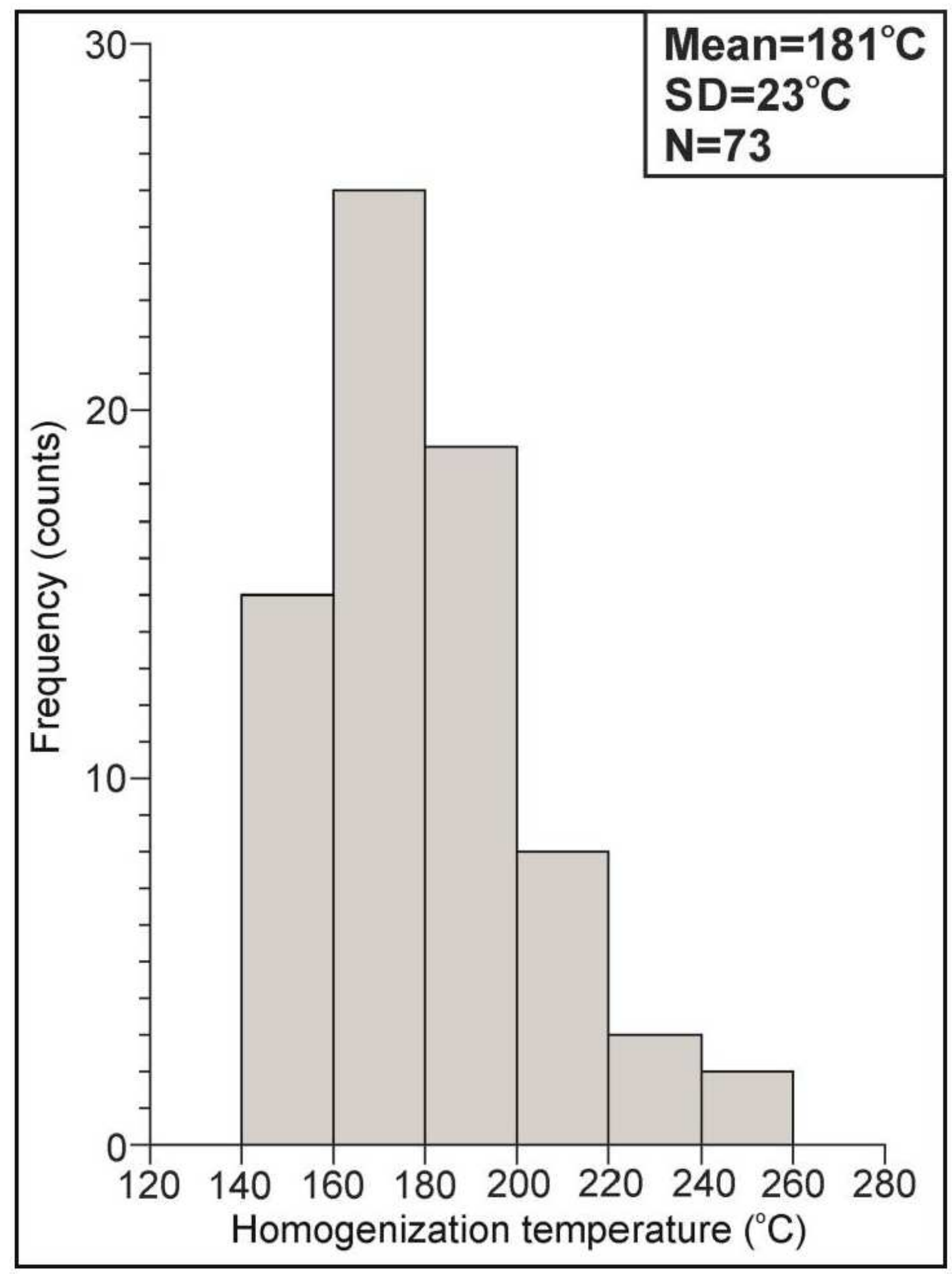

Figure 11

Histogram of homogenization temperatures $\left({ }^{\circ} \mathrm{C}\right)$ obtained for fluid inclusions hosted in barite from Jebel Ouichane. 